Linköping Studies in Arts and Sciences No. 805

\title{
Uncharted Waters
}

\section{Non-target analysis of disinfection by-products in drinking water}

Anna Andersson

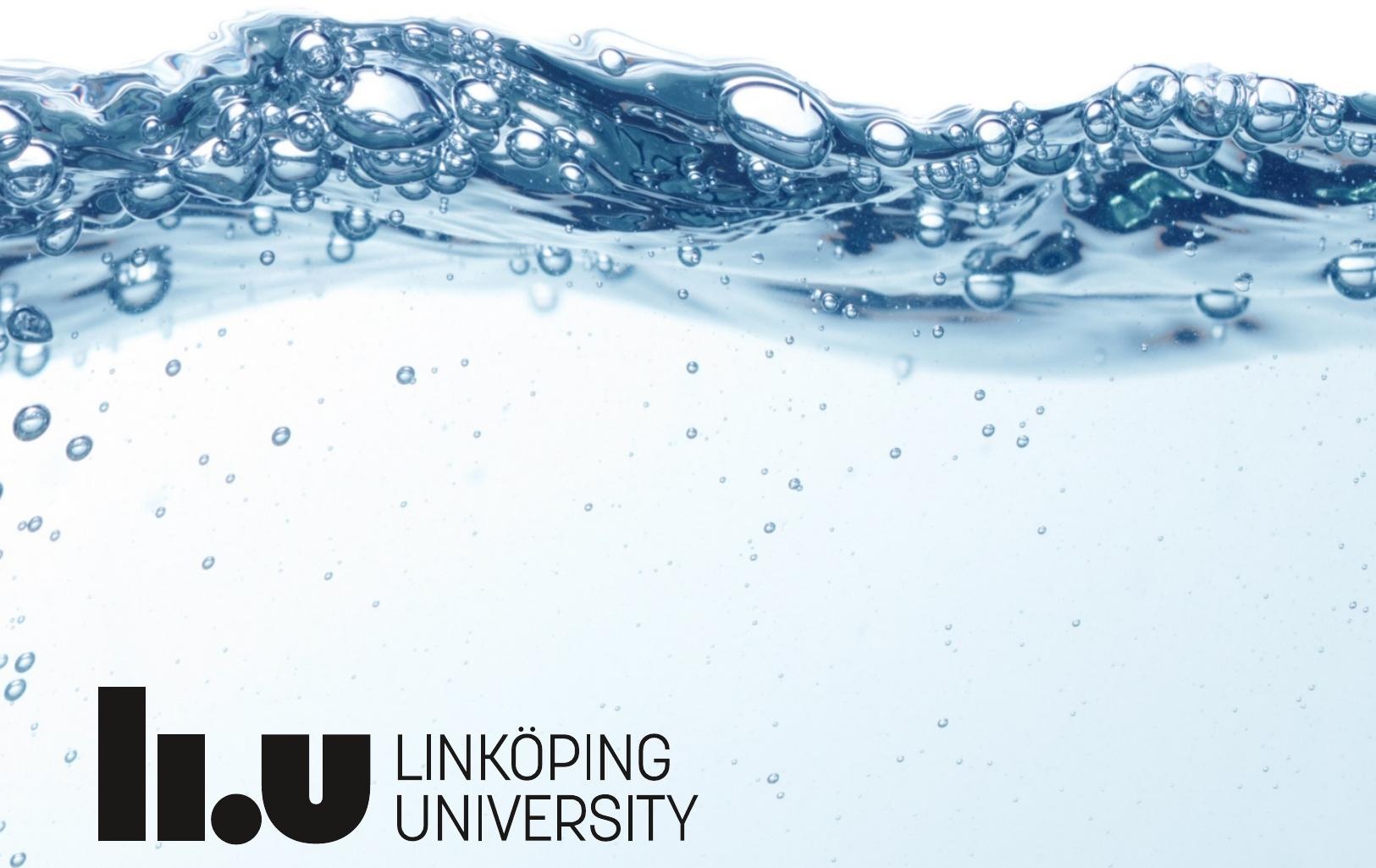





\section{Uncharted Waters}

\section{Non-target analysis of disinfection by-products in drinking water}

Anna Andersson

h.U UNKNERNG

Linköping Studies in Arts and Sciences No. 805

Department of Thematic Studies - Environmental Change

Faculty of Arts and Sciences

Linköping 2021 
Linköping Studies in Arts and Sciences · No. 805

At the Faculty of Arts and Sciences at Linköping University, research and doctoral studies are carried out within broad problem areas. Research is organized in interdisciplinary research environments and doctoral studies mainly in graduate schools. Jointly, they publish the series Linköping Studies in Arts and Sciences. This thesis comes from the Department of Thematic Studies - Environmental Change.

Distributed by:

Department of Thematic Studies - Environmental Change

Linköping University

58183 Linköping

Author: Anna Andersson

Title: Uncharted Waters: Non-target analysis of disinfection by-products in drinking water

Edition 1:1

ISBN 978-91-7929-694-0

ISSN 0282-9800

(C) Anna Andersson

Department of Thematic Studies - Environmental Change 2021

Printed by: LiU-Tryck, Linköping 2021

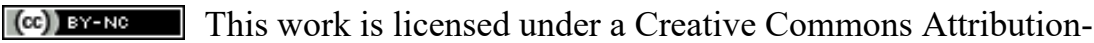
NonCommercial 4.0 International License.

https://creativecommons.org/licenses/by-nc/4.0/ 


\section{Abstract}

Disinfection by-products (DBPs) are potentially toxic compounds formed when drinking water is treated with disinfectants, such as chlorine or chloramine. A large proportion of the exposure to DBPs is still unknown and the health risks observed through epidemiological studies cannot be explained by DBPs known today. In this thesis, a part of the unknown DBP fraction is investigated, covering a wide range of non-volatile, chlorine/bromine-containing DBPs. The goals were to investigate how the compositions of these DBPs differ between water treatment plants, how their occurrence changes in the distribution system until reaching consumers and how new treatment techniques can reduce their formation and toxicity. To analyze unknown DBPs, a non-targeted approach adopting ultra-high-resolution mass spectrometry, Fourier transform ion cyclotron resonance mass spectrometry (FT-ICR MS), was used, where the mass of molecules is measured with such accuracy that the elemental composition of individual DBPs can be calculated. A panel of bioassays was used to assess the combined toxic effects from these DBP mixtures.

The results show that the formation of these DBPs to a large extent was specific to each water treatment plant and that local conditions influenced DBP formation, based on e.g., the abundance of organic material with certain chemical structures, bromide and disinfection procedure and agent (chlorine or chloramine). The DBPs were detected in both chlorinated and chloraminated water and in all tap water samples, demonstrating that they are part of human exposure. The number of DBP formulae decreased and the DBP composition changed between drinking water treatment and consumer taps, suggesting that DBP exposure to consumers is not necessarily resembling measurements at the treatment plants. Evaluation of new treatment techniques showed that suspended ion exchange and ozonation have potential to decrease the formation and toxic effects of DBPs and that the removal of organic matter can influence qualitative aspects of DBP formation, such as the proportions of chlorine-containing (less toxic) versus bromine-containing (more toxic) DBPs. Through increased knowledge about the role and relevance of non-volatile DBPs, this work can contribute to future monitoring and actions to reduce the health risks associated with DBPs in chlorinated or chloraminated drinking water. 



\section{Sammanfattning}

Desinfektionsbiprodukter (DBP:s) är potentiellt giftiga ämnen som bildas när dricksvatten renas med desinfektionsmedel såsom hypoklorit eller monokloramin. En stor del av exponeringen är ännu okänd och hittills kända DBP:s kan inte förklara de hälsorisker som förknippats med klorerat dricksvatten i epidemiologiska studier. I avhandlingen undersöks en relativt okänd fraktion av DBP:s som utgörs av icke-flyktiga, klor/brominnehållande ämnen. Målen var att undersöka hur dessa DBP:s varierar mellan olika vattenverk, om de förekommer hos konsumenter och hur nya vattenreningstekniker kan minska dess bildandning och relaterad toxicitet. För att mäta okända DBP:s användes ultrahögupplöst masspektrometri (Fourier transform ion cyclotron resonance mass spectrometry (FT-ICR MS)), med vilken massan hos molekyler kan bestämmas så exakt att atomsammansättningen för enskilda DBP:s kan räknas ut. En serie effektbaserade metoder som bygger på biologiska testsystem användes för att mäta kombinerade toxiska effekter från de studerade biprodukterna.

Resultaten visar att största delen av bildade DBP:s var unik för varje vattenverk och att lokala förutsättningar påverkar vilka DBP:s som bildas, till exempel om det finns organiskt material med särskilda kemiska strukturer, bromid eller vilket desinfektionsmedel (klor eller kloramin) som används. De studerade biprodukterna detekterades både i klorerat och kloraminerat dricksvatten och i samtliga kranvatten, vilket innebär att de bidrar till konsumenters exponering. Antalet detekterade DBP:s minskade och sammansättningen ändrades mellan vattenverk och konsument, vilket innebär att DBP exponeringen hos konsumenter inte är densamma som mäts på vattenverken. En utvärdering av nya reningstekniker visade att suspenderat jonbyte och ozonering har potential att minska bildning och relaterad toxisk effekt från DBP:s och att borttagning av organiskt material kan påverka kvalitativa aspekter av DBP bildning, såsom proportionerna av klorerade (mindre toxiska) och bromerade (mer toxiska) DBP:s. Genom ökad insikt om icke-flyktiga DBP:s roll och relevans kan detta arbete bidra till att förbättra framtida uppföljning och insatser för att minska hälsorisker kopplade till DBP:s i klorerat eller kloraminerat dricksvatten. 



\section{List of papers}

I Anna Andersson, Mourad Harir, Michael Gonsior, Norbert Hertkorn, Philippe Schmitt-Kopplin, Henrik Kylin, Susanne Karlsson, Muhammad Jamshaid Ashiq, Elin Lavonen, Kerstin Nilsson, Ämma Pettersson, Helena Stavklint and David Bastviken. 2019. Waterworks-specific composition of drinking water disinfection by-products. Environmental Science: Water Research \& Technology, 5, 861-872.

II Anna Andersson, Michael Gonsior, Mourad Harir, Norbert Hertkorn, Philippe Schmitt-Kopplin, Leanne Powers, Henrik Kylin, Daniel Hellström, Kerstin Nilsson, Ämma Pettersson, Helena Stavklint and David Bastviken. Molecular changes among non-volatile disinfection by-products between drinking water treatment and consumer taps. To be submitted.

III Anna Andersson, Elin Lavonen, Mourad Harir, Michael Gonsior, Norbert Hertkorn, Philippe Schmitt-Kopplin, Henrik Kylin, and David Bastviken. 2020. Selective removal of natural organic matter during drinking water production changes the composition of disinfection by-products. Environmental Science: Water Research \& Technology, 6, 779-794.

IV Johan Lundqvist, Anna Andersson, Anders Johannisson, Elin Lavonen, Geeta Mandava, Henrik Kylin, David Bastviken, and Agneta Oskarsson. 2019. Innovative drinking water treatment techniques reduce the disinfection-induced oxidative stress and genotoxic activity. Water Research, 155, 182-192. 



\section{Contribution to papers}

I Planned and performed the sampling, laboratory work and data analysis of this study and led the writing process of the paper. Mourad Harir operated the FT-ICR MS instrument.

II Planned and performed the sampling, laboratory work and data analysis of this study and led the writing process of the paper. Mourad Harir operated the FT-ICR MS instrument.

III Planned and performed the sampling, experimental and laboratory work and data analysis of this study and led the writing process of the paper. Mourad Harir operated the FT-ICR MS instrument.

IV Planned and performed the sampling, experimental and laboratory work of this study and participated in data evaluation and the writing process. Johan Lundqvist led the laboratory work related to the bioassays and subsequent data analysis. 



\section{Abbreviations}

AOX Adsorbable organic halogens

Br-DBP Bromine-containing disinfection by-product

Cl-DBP Chlorine-containing disinfection by-product

$\mathrm{ClO}^{-} \quad$ Hypochlorite

DBE Double bond equivalences

DBPs Disinfection by-products

DOC Dissolved organic carbon

DOM Dissolved organic matter

ESI Electrospray ionization

FT-ICR Fourier transform ion cyclotron resonance

GAC Granular activated carbon

GC Gas chromatography

HAAs Haloacetic acids

$\mathrm{HOBr}$ Hypobromous acid

$\mathrm{HOCl}$ Hypochlorous acid

LC-OCD Liquid chromatography organic carbon detection

MS Mass spectrometry

$\mathrm{NH}_{2} \mathrm{Cl}$ Monochloramine

NOM Natural organic matter

REF Relative enrichment factor

SIX Suspended ion exchange

SPE Solid phase extraction

SUVA Specific ultraviolet absorbance

THMs Trihalomethanes

TOX Total organic halogens

$\mathrm{UVA}_{254} \quad$ Ultraviolet absorbance, measured at $254 \mathrm{~nm}$

WTP Water treatment plant 



\section{Acknowledgements}

I am grateful. To many. The Swedish Research Council for Sustainable Development, FORMAS, granted this project and Svenskt Vatten Utveckling, Norrvatten, and Stockholm Vatten och Avfall, funded the pilot plant project, which I was invited to participate in. My supervisors have provided grand support. David Bastviken, my main supervisor, has encouraged me and steadily guided me in research from day one, or even before that, because I asked for potential master projects years ahead. Henrik Kylin and I have had long enjoyable chemistry talks ("let's start at 15, then we can go on as long as we want") and he taught me the art of writing. With Susanne Karlsson, I have bounced many ideas and practical matters (and these things are more important than most people seem to think) and Nguyen Thanh Duc taught me another form of art, Matlab. It is beautiful.

I want to thank the helpful staff at the treatment plants, those who met me up early to start collecting samples or stayed late in the lab until I was done. I am grateful for all nice breakfast/"fika"-times we had, probably my favorite parts. I think coffee breaks are intrinsic features of me. When I came to my colleagues in Munich it seemed like I had an influence on coffee-break frequency, even at department level. To the Munich-team, Mourad, Norbert, Michael (living in the United States, but still fitting well into this categorization) and Phil, I am very grateful for your major efforts contributing to this work, the very engaging collaboration and overall nice times spent together, watching excellent champions league football games and sharing unforgettable story-telling moments around a campfire in the Tiveden national park.

Elin Lavonen contributed extensively to this project through her dual insight in academia and the drinking water sector. At a workshop, Agneta Oskarsson approached me, asking if we should do research together. Yes! Let's! I am very grateful for that question and the inspiring interdisciplinary collaboration (also including Johan Lundqvist) that it led to.

Now it's time to wrap up, but there are many to thank still. All my fellow PhDs at the department, the research engineers, the two students who assisted me during sample collection, teachers (my chemistry teacher at high-school, Sture, was also my supervisor David's teacher (crazy!)), colleagues, colleagues at previous workplaces (Angela and Siros at SYNLAB, taught me everything about standard procedures and the practical art of chemical analysis, including almost endless traceability).

I will end by thanking the ones in my inner circle. Dad, my role model, who always encouraged me and taught me how to learn new things and many other skills that enabled me to take on this challenge. Mum, she 
always laughs when I try to make a joke. Ebba, my daughter and sunshine. Elias, my husband who shared all parts of this journey with me. He usually met me up when I came back from sampling, to help me unload the Toyota Hilux. One of those times, he brought freshly baked cinnamon buns and a bottle of milk (a great combination), saying something about the fantastic encouragement and support he gave me.

Finally, the joy of the Lord is my strength. I am grateful. 


\section{Table of contents}

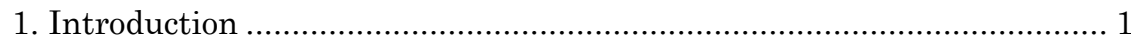

2. Research objectives ........................................................................ 3

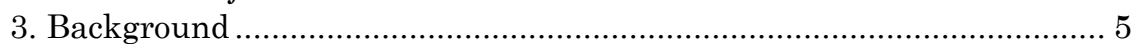

3.1 The first DBP was discovered in the $1970 \mathrm{~s}$........................... 5

3.2 Introduction to DBP formation................................................ 6

3.2.1 Chlorine and chloramine chemistry............................... 6

3.2.2 DBP reactions are substitution reactions ......................... 7

3.2.3 Important factors.......................................................... 8

3.2.4 Natural organic matter constitutes DBP precursors ........ 10

3.3 Gas chromatography has dominated DBP analysis ............... 11

4. Methodology .......................................................................................... 15

4.1 Mapping DBP formation at four WTPs using different raw water types (Papers I, II) ............................................................ 15

4.1.1 Site selection and sample collection.............................. 15

4.1.2 Choice of methods ............................................................. 17

4.1.3 FT-ICR MS analysis .................................................... 18

4.1.4 Standard methods for water characterization.................. 20

4.2 NOM removal and DBP formation at a novel pilot-scale treatment process (Papers III, IV) ........................................... 21

4.2.1 The pilot-scale process, sample collection and experimental design ........................................................... 21

4.2.2 Choice of methods ............................................................. 22

4.2.3 AOX analysis............................................................... 23

4.2.4 Bioassays.......................................................................... 23

4.3 Use of quenching agents................................................... 24

4.4 Method limitations............................................................. 24

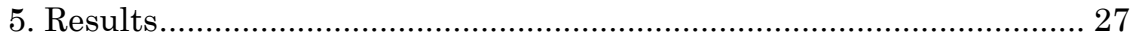

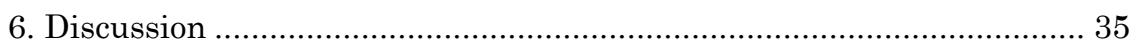

6.1 DBP formation from chlorine vs chloramine disinfection ........ 35

6.2 NOM and formation of non-volatile DBPs ............................ 35

6.3 Potential of suspended ion exchange ................................... 36

6.4 But what is in the tap? ................................................. 37

6.5 Method reflections.............................................................. 38 
6.6 Future perspectives................................................... 39

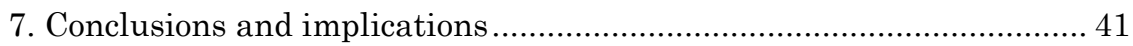

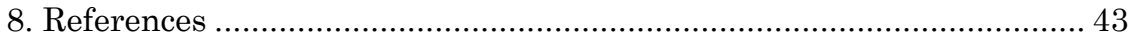

Appendix ....................................................................................... 53

Appendix A: Summary of conventional water treatments ........... 53

Appendix B: Summary of novel water treatments ..................... 56

Appendix C: Principles of FT-ICR MS analysis ......................... 58

Appendix D: An FT-ICR mass spectrum - what does it look like?60

Appendix E: FT-ICR MS data analysis and interpretation

62 


\section{Introduction}

Waterborne diseases have been and continue to be a major problem in many parts of the world. When disinfectants, such as chlorine, were introduced to drinking water treatment in the early $1900 \mathrm{~s}$, the cases of waterborne diseases declined dramatically (EPA, 2000). Disinfectants are strong oxidizing agents that effectively inactivate pathogens by oxidizing organic molecules (Richardson and Ternes, 2011). Chlorine is the most widely used disinfectant because of its high efficiency and low cost, but other disinfectants, such as chloramine, chlorine dioxide and ozone are also used (Villanueva et al., 2015, Serrano et al., 2015).

A downside of chemical disinfection is that so-called disinfection byproducts (DBPs) can form when the disinfectants react with natural organic matter (NOM) (Richardson et al., 2007, Deborde and von Gunten, 2008). DBPs are of concern due to their toxicity and carcinogenicity (Richardson et al., 2007). Humans are exposed to an as-yet unknown cumulative cancer risk from environmental pollutants, including DBPs. The lifetime cancer risk from chlorinated drinking water in the USA has been estimated as approximately one additional cancer patient per thousand people (Bull et al., 2011). In Sweden, a recent epidemiological study found associations between exposure to chlorinated drinking water and decreased fetal growth (Säve-Söderbergh et al., 2020). However, the risks associated with the complex pool of DBPs have not yet been accounted for by actual DBP determination. Until recently, about $700 \mathrm{DBP}$ s had been identified. These known compounds account for fewer than 50\% of the total organic halogens (TOX) formed upon chlorination (Zhang et al., 2000, Hua and Reckhow, 2007b, Richardson and Ternes, 2018, Richardson et al., 2007). Consequently, a large proportion of the DBP mixture is still unknown.

The diversity of DBPs formed during chemical disinfection makes effective monitoring challenging. Today, 18 different DBPs are regulated by the US Environmental Protection Agency, the European Union and the World Health Organization, with four trihalomethanes (THMs) and five haloacetic acids (HAAs) being the most frequently monitored (Yang and Zhang, 2016). When these classes of DBPs were studied in experimental animals, they were found to be weak carcinogens (Bull et al., 2006). Compared with the results from epidemiological studies, there is a gap of two orders of magnitude between the risk associated with the intake of chlorinated drinking water and the toxicity of the regulated THMs and HAAs, assuming equivalent potency in humans as that found in experimental animals (Bull et al., 2011). Hence, the most prevalent DBPs are not likely to be responsible for the assessed health risks, and some groups of DBPs are toxic even at very low concentrations (Richardson et 
al., 2007). The shift from chlorination to alternative disinfectants, such as chloramine and ozone, have resulted in lower concentrations of many of the regulated DBPs. However, they have instead created other, sometimes more toxic, DBPs (Goslan et al., 2009, Richardson and Ternes, 2011) and overall higher proportions of unknown DBPs (Zhang et al., 2000).

New approaches are needed to develop the understanding of the unknown components of DBP exposure. Novel instrumentation for the detailed characterization of organic compounds in complex mixtures, including ultrahigh-resolution Fourier transform ion cyclotron resonance mass spectrometry (FT-ICR MS), create opportunities for a new way of studying DBPs using a non-targeted approach. Due to its very high mass resolution and mass accuracy, FT-ICR MS allows characterization down to elemental compositions at a molecular scale (Koch et al., 2005). This approach enables the screening of halogenated organic compounds not yet determined using other methods.

DBP formation depend largely on available NOM (Hua et al., 2015). NOM comprises compounds originated from lipids, proteins, carbohydrates or lignin (Perdue, 2009). The abundance and characteristics of available NOM depend on the water source, as well as treatment processes capable of removing NOM prior to disinfection. In Sweden, conventional treatment techniques, such as coagulation, are common. However, challenges associated with increased levels or fluctuations of source water NOM are becoming problematic for some drinking water producers (Evans et al., 2005, Hongve et al., 2004). Therefore, updated treatment systems featuring new techniques are likely to be needed to meet future challenges. One such treatment system investigated for Swedish drinking water production includes suspended ion exchange, ozonation, in-line coagulation and micro-filtration through a ceramic membrane followed by granular activated carbon filtration. This treatment chain is expected to have a large impact on DBP formation (Metcalfe et al., 2015) and requires evaluation for its potential to reduce DBP exposures.

Given the large complexity of DBP mixtures, involving unknown components, a major challenge in the evaluation of DBP formation is to acquire data that provide solid grounds for decision-making (Altenburger et al., 2019). By combining chemical analysis with toxicological assessments of DBP mixtures, complementary information can be gained, accounting for the differences in toxicity among DBPs. 


\section{Research objectives}

The objective of this thesis was to explore yet unknown components of the DBP mixture in drinking water and study their formation in connection to NOM characteristics and disinfectants (chlorine vs chloramine) and their potential relevance for human exposure. Listed below are the specific research questions addressed in this thesis.

- How does the composition of formed DBPs differ between water treatment plants using different raw water sources, treatments, and disinfectants? (Paper I)

- How does DBP composition change between the point of disinfection and a consumer's tap? (Paper II)

- How are NOM and DBP composition, formation potential and mixture toxicity affected by suspended ion exchange (SIX®), ozonation, ceramic micro-filtration (CeraMac $®)$ with in-line coagulation and granular activated carbon (GAC) filtration? (Papers III and IV) 



\section{Background}

\subsection{The first DBP was discovered in the 1970s}

The first disinfection by-product (DBP) was discovered in the early 1970s, when J.J. Rook detected chloroform in chlorinated drinking water (Rook, 1974). Epidemiological studies have shown that long-term exposure to chlorinated drinking water is associated with an increased risk of bladder cancer (Villanueva et al., 2015) and also to other health risks, including adverse reproductive outcomes, although more studies are needed to confirm these associations (Bove et al., 2002, Nieuwenhuijsen et al., 2000, Waller et al., 1998).

Since the discovery of chloroform, which belongs to a class of DBPs called trihalomethanes (THMs), several other classes have been discovered, including haloacetic acids (HAAs), haloacetonitriles, haloamides, haloketones, halonitromethanes, 3-Chloro-4-(dichloromethyl)5-hydroxy-2(5H)-furanone (MX) and halobenzoquinones (Richardson et al., 2007, Qin et al., 2010, Hua and Reckhow, 2007b). In the USA, 11 DBPs are currently regulated under the Stage 2 D/DBP rule (EPA, 2006), while a smaller number is regulated in Europe and Sweden (EU, 1998, Livsmedelsverket, 2015). A summary of current regulatory limits is presented in Table 1.

Table 1. Summary of regulatory limits for DBPs in the USA, Europe, and Sweden (EPA, 2006, EU, 1998, Livsmedelsverket, 2015). The total level of THMs (TTHM) include chloroform, bromodichloromethane, chlorodibromomethane and bromoform. The five haloacetic acids (HAA5) are chloroacetic acid, bromoacetic acid, dichloroacetic acid, dibromoacetic acid and trichloroacetic acid. In Sweden, TTHM is regulated at two levels; the upper one being the sharp regulatory limit and the lower being the limit for drinking water with no remarks. NR $=$ Not regulated.

\begin{tabular}{llll}
\hline Regulated DBP & USA & Europe & Sweden \\
\hline TTHM $(\mu \mathrm{g} / \mathrm{l})$ & 80 & 100 & $100(50)$ \\
HAA5 $(\mu \mathrm{g} / \mathrm{l})$ & 60 & $\mathrm{NR}$ & $\mathrm{NR}$ \\
Bromate $(\mu \mathrm{g} / \mathrm{l})$ & 10 & 10 & $\mathrm{NR}$ \\
Chlorite $(\mu \mathrm{g} / \mathrm{l})$ & 1000 & $\mathrm{NR}$ & $\mathrm{NR}$ \\
\hline
\end{tabular}


Many of the known DBPs are cytotoxic, mutagenic, genotoxic, carcinogenic, neurotoxic and teratogenic (Richardson et al., 2007), but their toxicity varies substantially between classes and species. Nitrogen-containing DBPs, such as haloacetonitriles and halonitromethanes have higher genotoxicity and cytotoxicity compared to THMs and HAAs (Plewa et al., 2008). Also, iodine- and bromine-containing DBPs (I-DBPs, Br-DBPs) are more genotoxic and cytotoxic compared to chlorine-containing DBPs $(\mathrm{Cl}$ DBPs), which is linked to the halogens' different propensity as leaving group (Plewa et al., 2008, Woo et al., 2002, Richardson et al., 2007).

\subsection{Introduction to DBP formation}

\subsubsection{Chlorine and chloramine chemistry}

Disinfection of drinking water using chemical oxidants serves two main purposes. The primary purpose is to kill (inactivate) pathogens and the secondary is to prevent microbial regrowth in the distribution system by providing a disinfectant residual (Xie, 2004).

\section{Chlorination}

In water treatment, typically gaseous chlorine $\left(\mathrm{Cl}_{2}\right)$ or hypochlorite $\left(\mathrm{ClO}^{-}\right)$ is used for chlorination. The chlorine species that are reacting to form DBPs are highly dependent on $\mathrm{pH}$. When $\mathrm{Cl}_{2}$ is dissolved in water, hypochlorous acid $(\mathrm{HOCl})$ is formed in the fast hydrolysis reaction (Reaction 1) (Faust and Aly, 1983):

$$
\mathrm{Cl}_{2}+2 \mathrm{H}_{2} \mathrm{O} \rightleftarrows \mathrm{H}_{3} \mathrm{O}^{+}+\mathrm{Cl}^{-}+\mathrm{HOCl} \quad \text { (Reaction 1) }
$$

At $\mathrm{pH}$ above 3 , very little molecular chlorine $\left(\mathrm{Cl}_{2}\right)$ is present and the dominant form is hypochlorous acid, $\mathrm{HOCl}$, (Deborde and von Gunten, 2008). $\mathrm{HOCl}$ is a weak acid and undergoes dissociation at higher $\mathrm{pH}$ $\left(\mathrm{pK}_{\mathrm{a}}=7.54\right.$ at $25^{\circ} \mathrm{C}$, Reaction 2) (Morris, 1966).

$$
\mathrm{H}_{2} \mathrm{O}+\mathrm{HOCl} \rightleftarrows \mathrm{H}_{3} \mathrm{O}^{+}+\mathrm{ClO}^{-}
$$

(Reaction 2)

Hence, for $\mathrm{pH}$ above 7.6 the hypochlorite ion, $\mathrm{ClO}^{-}$, is often the dominant form of chlorine. For disinfection, the distribution between $\mathrm{HOCl}$ and $\mathrm{ClO}^{-}$, is important because the two forms have different biocidal activity, i.e., capacity to inactivate microorganisms, with $\mathrm{HOCl}$ being more effective (Faust and Aly, 1983). The dosage of chlorine is set based on the chlorine demand, i.e., the amount of chlorine that is consumed by e.g., ammonia and other inorganic compounds under specified $\mathrm{pH}$ and temperature conditions, resulting in a desired level of residual chlorine being available for disinfection (Edzwald, 2012). The total levels of $\mathrm{HOCl}, \mathrm{ClO}^{-}$and $\mathrm{Cl}_{2}$ are measured and referred to as free chlorine. 


\section{Chloramination}

Chloramine has a milder disinfection capability than chlorine and is usually used as a secondary disinfectant due to its persistence and longlasting effect. Compared to chlorine, a contact time of about 100 times longer is needed for a $100 \%$ kill when chloramine is used (equal quantities of disinfectants used) (Butterfield and Wattie, 1946). Chloramines are formed in water solution when hypochlorous acid reacts with ammonia (Faust and Aly, 1983) (Reaction 3). The first chloramine to form is monochloramine $\left(\mathrm{NH}_{2} \mathrm{Cl}\right)$, which can further react with hypochlorous acid to form dichloramine and trichloramine $\left(\mathrm{NHCl}_{2}\right.$ and $\mathrm{NCl}_{3}$, respectively; Reactions 4 and 5).

$$
\begin{array}{lll}
\mathrm{NH}_{3}+\mathrm{HOCl} \rightleftarrows \mathrm{NH}_{2} \mathrm{Cl}+\mathrm{H}_{2} \mathrm{O} & \text { (Reaction 3) } \\
\mathrm{NH}_{2} \mathrm{Cl}+\mathrm{HOCl} \rightleftarrows \mathrm{NHCl}_{2}+\mathrm{H}_{2} \mathrm{O} & \text { (Reaction 4) } \\
\mathrm{NHCl}_{2}+\mathrm{HOCl} \rightleftarrows \mathrm{NCl}_{3}+\mathrm{H}_{2} \mathrm{O} & \text { (Reaction 5) }
\end{array}
$$

The form of chloramine present depends on $\mathrm{pH}$ and the relative concentrations of $\mathrm{HOCl}$ and $\mathrm{NH}_{3}$. For $\mathrm{pH}$ above 8, a typical $\mathrm{pH}$ during chemical disinfection at water treatment plants in Sweden, monochloramine is the dominant form (Faust and Aly, 1983). Chloramines are measured and referred to as combined chlorine, since the chlorine is no longer "free" but combined with ammonia. Total chlorine refers to the sum of free and combined chlorine.

\subsubsection{DBP reactions are substitution reactions}

This section focusses on the principles of chlorine reactions. Chemical reactions involving chloramine are more complex (Heeb et al., 2014, Zhu and Zhang, 2016) and are briefly described in section 3.2.3 and Figure 2. Hypochlorous acid can react with organic molecules in three different ways: through oxidation reactions, addition reactions to unsaturated bonds or through electrophilic substitution at sites which are nucleophilic, i.e., can donate electrons (Deborde and von Gunten, 2008). The selectivity of hypochlorous acid reactions limits the reaction to certain sites of the organic molecule. Both addition and substitution reactions can result in halogenated DBPs, but because addition reactions have low chlorination rate constants under typical water treatment conditions, electrophilic substitution (of the second order) are likely to be most important for DBP formation (Zhu and Zhang, 2016, Deborde and von Gunten, 2008). A small molecule, such as propanone (acetone), can be used to illustrate the reaction. Here, propanone is oxidized by hypochlorous acid into trichloropropanone (Reactions 6-8), referred to as intermediate DBPs, and undergo a hydrolysis reaction to form chloroform (Reaction 9), referred to as an end DBP (Xie, 2004): 


$$
\begin{array}{ll}
\mathrm{CH}_{3} \mathrm{COCH}_{3}+\mathrm{HOCl} \rightarrow \mathrm{CH}_{2} \mathrm{ClCOCH}_{3}+\mathrm{H}_{2} \mathrm{O} & \text { (Reaction 6) } \\
\mathrm{CH}_{2} \mathrm{ClCOCH}_{3}+\mathrm{HOCl} \rightarrow \mathrm{CHCl}_{2} \mathrm{COCH}_{3}+\mathrm{H}_{2} \mathrm{O} & \text { (Reaction 7) } \\
\mathrm{CHCl}_{2} \mathrm{COCH}^{3}+\mathrm{HOCl} \rightarrow \mathrm{CCl}_{3} \mathrm{COCH}_{3}+\mathrm{H}_{2} \mathrm{O} & \text { (Reaction 8) } \\
\mathrm{CCl}_{3} \mathrm{COCH}_{3}+\mathrm{H}_{2} \mathrm{O} \rightarrow \mathrm{CH}_{3} \mathrm{COOH}+\mathrm{CHCl}_{3} & \text { (Reaction 9) }
\end{array}
$$

The electrophilic substitution is caused by the partial positive charge on the chlorine atom in the $\mathrm{HOCl}$ molecule (Voudrias and Reinhard, 1988) (oxygen is more electronegative than chlorine) and the donation of electrons from the reacting organic molecule (Deborde and von Gunten, 2008). When all feasible positions are substituted by halogen atoms, further halogenation results in ring opening (if aromatic molecules) and THM formation (Heeb et al., 2014).

\subsubsection{Important factors}

An overview of the important factors guiding DBP formation is shown in Figure 1. The choice of disinfectant influences DBP formation. For chlorine and chloramine, one DBP reaction pathway is identical (Vikesland et al., 1998), the reaction through $\mathrm{HOCl}$ (Figure 2), while the reaction directly through $\mathrm{NH}_{2} \mathrm{Cl}$ is unique for and has been suggested to dominate $(\approx 75-99 \%$ depending on $\mathrm{pH}$ ) during chloramination (Zhu and Zhang, 2016). Partly explained by these different reaction pathways (Wu et al., 2003), lower levels of THMs, HAAs and total organic halogens (TOX) are usually formed during chloramination compared to chlorination (Krasner et al., 2006). Instead, a higher occurrence of intermediate DBPs, such as dihalogenated compounds, is found after chloramination, along with overall larger proportions of unknown DBPs (Zhang et al., 2000, Hua and Reckhow, 2007b, Bougeard et al., 2010).

Disinfectant dose and contact time can alter the relationship between intermediate and end DBP products, with a higher dose leading to a greater proportion of end products, such as THMs (Xie, 2004, Hua and Reckhow, 2008). Increased contact time typically leads to higher proportions of known DBPs during chlorination while the opposite has been observed during chloramination (Hua and Reckhow, 2008). The dose in relation to levels of bromide or iodide in the source water can affect the extent of mixed halide DBP formation. When, for example, bromide is present in the source water, it is oxidized to hypobromous acid ( $\mathrm{HOBr}$ ) by $\mathrm{HOCl}$ (Reaction 10), and $\mathrm{HOBr}$ can react in a similar way to $\mathrm{HOCl}$ to form Br-DBPs (Reaction 11, note that this reaction is not balanced) (Sharma et al., 2014). Chloramine can also form Br-DBPs according to a similar switch of reacting molecule from $\mathrm{NH}_{2} \mathrm{Cl}$ to $\mathrm{NH}_{2} \mathrm{Br}$ in the presence of bromide (Figure 2).

$$
\begin{aligned}
& \mathrm{HOCl}+\mathrm{Br}^{-} \rightarrow \mathrm{HOBr}+\mathrm{Cl}^{-} \\
& \mathrm{HOBr}+\mathrm{NOM} \rightarrow \mathrm{Br}-\mathrm{DBPs}
\end{aligned}
$$$$
\text { (Reaction 10) }
$$ 


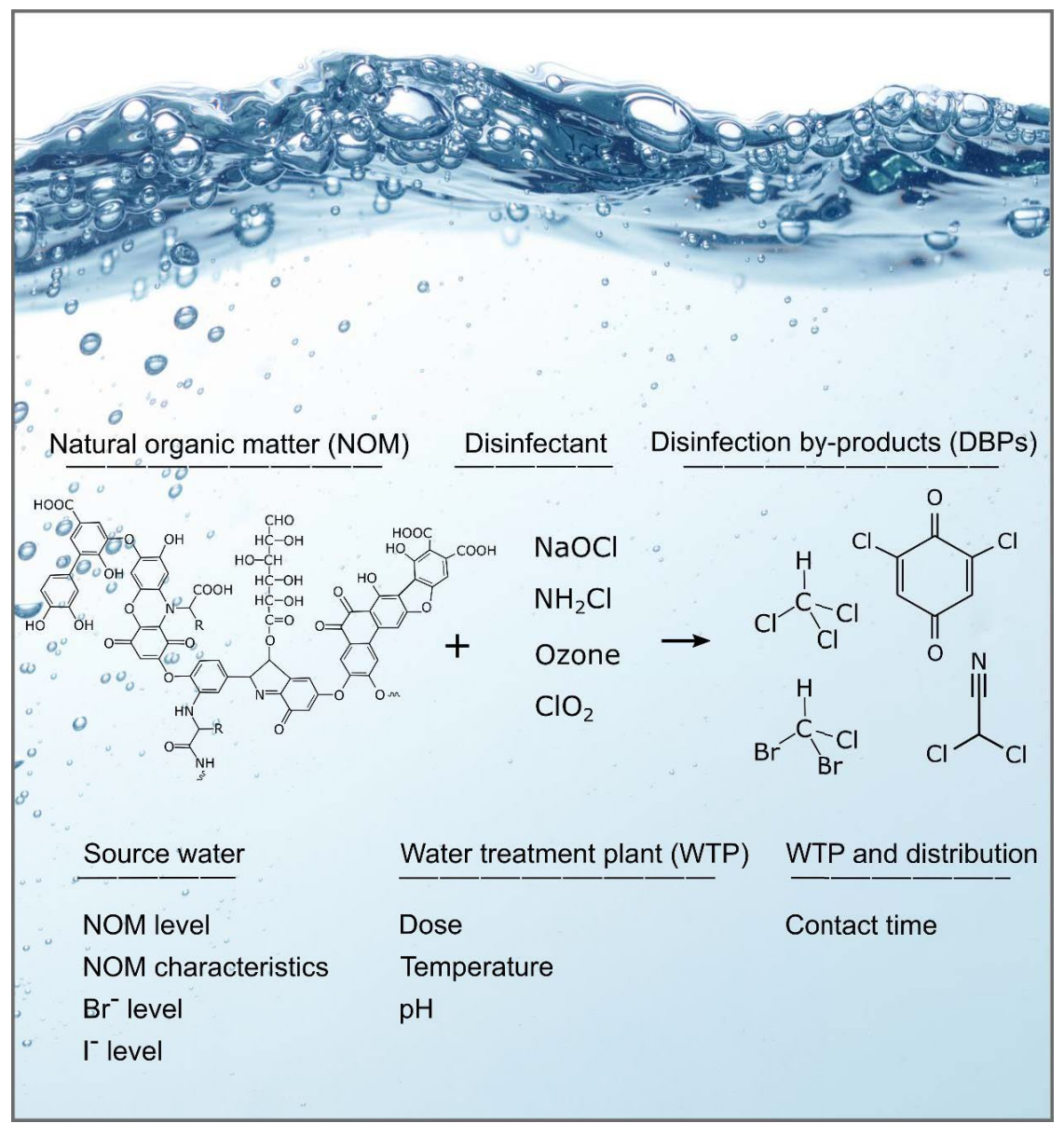

Figure 1. Schematic overview of DBP formation. Below the schematic reaction, the factors known to influence DBP formation are listed (Liang and Singer, 2003). Note that just a few examples of DBPs are shown. 


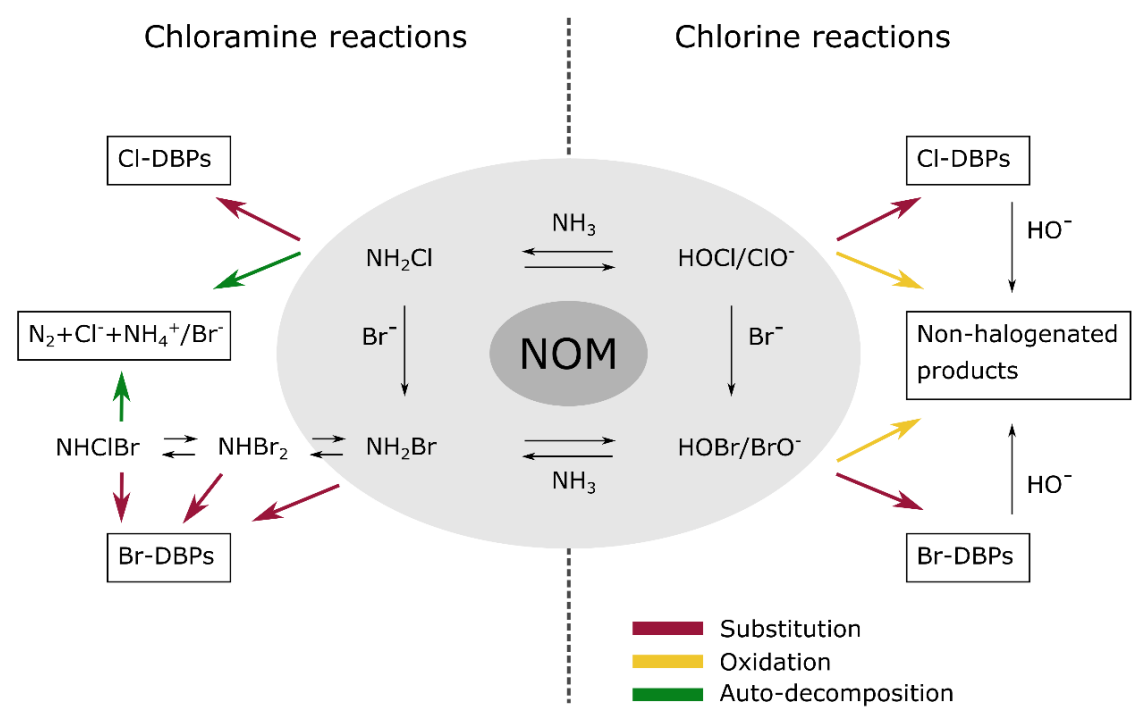

Figure 2. Important reaction pathways for DBP formation during chlorination and chloramination, revised and simplified from (Zhu and Zhang, 2016).

$\mathrm{pH}$ affects which form of chlorine that dominates (Reaction 2), the equilibrium of certain NOM molecules, e.g., dissociation of phenol to phenolate, which is more reactive (Gallard and von Gunten, 2002), as well as the conditions for certain reaction pathways, such as the hydrolysis reaction, which leads to e.g. THM formation and is favored under alkaline conditions (Liang and Singer, 2003). Hence, a change of $\mathrm{pH}$ can increase the formation of certain DBPs while decreasing the formation of others. Water temperature impacts upon the reaction rates of different DBP formation (Zhang et al., 2013, Abusallout et al., 2017), but in general, higher temperatures increase formation rates during both chlorination and chloramination and at warmer temperatures $\left(30^{\circ} \mathrm{C}\right)$, DBP formation shifts towards end DBPs during chlorination (Hua and Reckhow, 2008)

\subsubsection{Natural organic matter constitutes DBP precursors}

The reacting molecule, often called the precursor, is mainly NOM, such as humic or fulvic acids, but can also be anthropogenic compounds, such as pharmaceuticals (Richardson and Postigo, 2015, Wu et al., 2000, Zhang et al., 2000). To assess the effect that NOM characteristics have on DBP formation, different indicators to describe the organic material have been used. Examples include dissolved organic carbon (DOC), absorbance at $254 \mathrm{~nm}\left(\mathrm{UVA}_{254}\right)$, and specific ultraviolet absorbance (SUVA), which is the UV absorbance (typically determined at $254 \mathrm{~nm}$ ) normalized to DOC, and elemental analysis, such as $\mathrm{C} / \mathrm{H}$ and $\mathrm{C} / \mathrm{N}$ ratios $(\mathrm{Wu}$ et al., 2000, Chowdhury et al., 2009, Liang and Singer, 2003, Weishaar et al., 2003). 
SUVA, a parameter that depend on the presence of chromophores and is an indicator of the aromatic carbon content (Weishaar et al., 2003), has shown to correlate well with the formation of certain DBP species and with total organic halogen concentrations during chlorination and chloramination, especially for raw waters high in humic materials (Hua et al., 2015, Yang et al., 2008, Croué et al., 2000, Edzwald, 1993). Hydrophobic and high molecular mass NOM, e.g., $>0.5 \mathrm{kDa}$, have also been associated with the formation of unknown DBP components (Hua and Reckhow, 2007a, Hua et al., 2015). More specifically, activated aromatic structures, such as phenolic structures, have been identified as particularly reactive towards chlorine (Reckhow et al., 1990). However, for waters with little humic material, another fraction of NOM, neutral hydrophilic compounds, has been associated with the highest THM and HAA yields (Hwang et al., 2000). Also, the hydrophilic fraction of NOM, including organic compounds like aliphatic ketones, has been shown to be more reactive towards bromine (Liang and Singer, 2003, Heller-Grossman et al., 1993).

Different raw water sources, i.e., surface water or groundwater, can vary in NOM composition and relative distributions of hydrophilic and hydrophobic fractions (Rostad et al., 2000). Furthermore, different water treatment processes have different effect on NOM, which in turn affects the NOM pool present at the point of disinfection (Hua and Reckhow, 2013, Gonsior et al., 2014, Liang and Singer, 2003).

NOM levels are rising in many surface waters in northern Europe and the USA (Hongve et al., 2004, Evans et al., 2005), and conventional techniques, such as coagulation and sand filtration (further described in Appendix A), might not be sufficient to obtain the desired target NOM levels in treated water. Increasing levels of NOM can lead to increased DBP formation, but can also cause other problems, such as an increased risk of microbial growth in distribution systems and decreased efficiency of other treatment processes, such as granular activated carbon filtration or UV disinfection (Köhler et al., 2016). Hence, there is a need to evaluate new techniques for NOM removal and to understand how they can complement existing conventional treatments. The specific new treatment techniques evaluated in this thesis are further described in Appendix B.

\subsection{Gas chromatography has dominated DBP analysis}

There are many methods available for DBP determination (Yang and Zhang, 2016, Weinberg, 2009). Gas chromatography - mass spectrometry (GC/MS) has been important for the discovery of many DBPs and is suitable for low molecular mass, volatile compounds (Richardson, 2002). The extraction of analytes prior to GC analysis is a crucial step and different extraction techniques and solvents have been used to target various DBP groups (Weinberg, 2009, Ding and Chu, 2017, Yang and Zhang, 2016). Additional types or combinations of detectors have been used to fine-tune DBP analysis, such as electron capture detection or coupled MS/MS detection (Chinn et al., 2007, Yang and Zhang, 2016). Liquid chromatography - mass spectrometry (LC/MS) enables the determination 
of polar, hydrophilic and high molecular mass DBPs (Richardson, 2002, Weinberg, 2009). Given the difference in chemical structures of DBPs, several complementary analytical methods are necessary to capture the range of DBPs formed.

High-resolution MS techniques, such as magnetic sector mass spectrometers, time-of-flight analyzers, Orbitrap analyzers and Fourier transform ion cyclotron resonance (FT-ICR) mass spectrometers have emerged as important analytical tools to further identify unknown DBPs through accurate mass measurements and the determination of elemental compositions (Richardson and Postigo, 2016). A few studies have investigated DBP formation in this way (Gonsior et al., 2014, Lavonen et al., 2013, Zhang and Yang, 2018, Zhang et al., 2012a, Zhang et al., 2012b, Wang et al., 2017, Harris et al., 2015, Wang et al., 2016, Zhang et al., 2014), primarily focusing on lab experiments.

The total DBP pool constituting human exposure is complex and includes hundreds of DBPs at varying levels and toxicity. Given our incomplete knowledge of DBP composition, a large fraction of that exposure is unknown and not accounted for by known DBPs (Teuschler and Simmons, 2003, IARC, 2004, Bull et al., 2011). This challenge calls for methods capable of assessing the combined toxic effect of DBPs in a mixture, both known and unknown.

Several approaches based on in vitro bioassays, i.e., biological test systems outside of a living organism, have been tested for this purpose (Neale et al., 2012, Stalter et al., 2016a, Farré et al., 2013). These tests are based on measuring the activation of responses and defense mechanisms of early cellular events caused by the DBPs' reaction with molecular targets (Farré et al., 2013, Escher et al., 2012). Of the different bioassays tested so far, the induction of an oxidative stress response has been particularly sensitive to DBPs (Farré et al., 2013). The transcription factor Nrf2 regulates the cellular defense mechanism against oxidative stress in mammals and can activate genes that lead to the production of proteins with antioxidant and detoxifying capacity (Escher et al., 2012). When oxidative stress is induced via Nrf2 activation in the modified cells used in the bioassay (Figure 3), luciferase is expressed in amounts dependent on the activity, i.e., the Nrf2-induced activity can be quantified (Escher et al., 2012). 


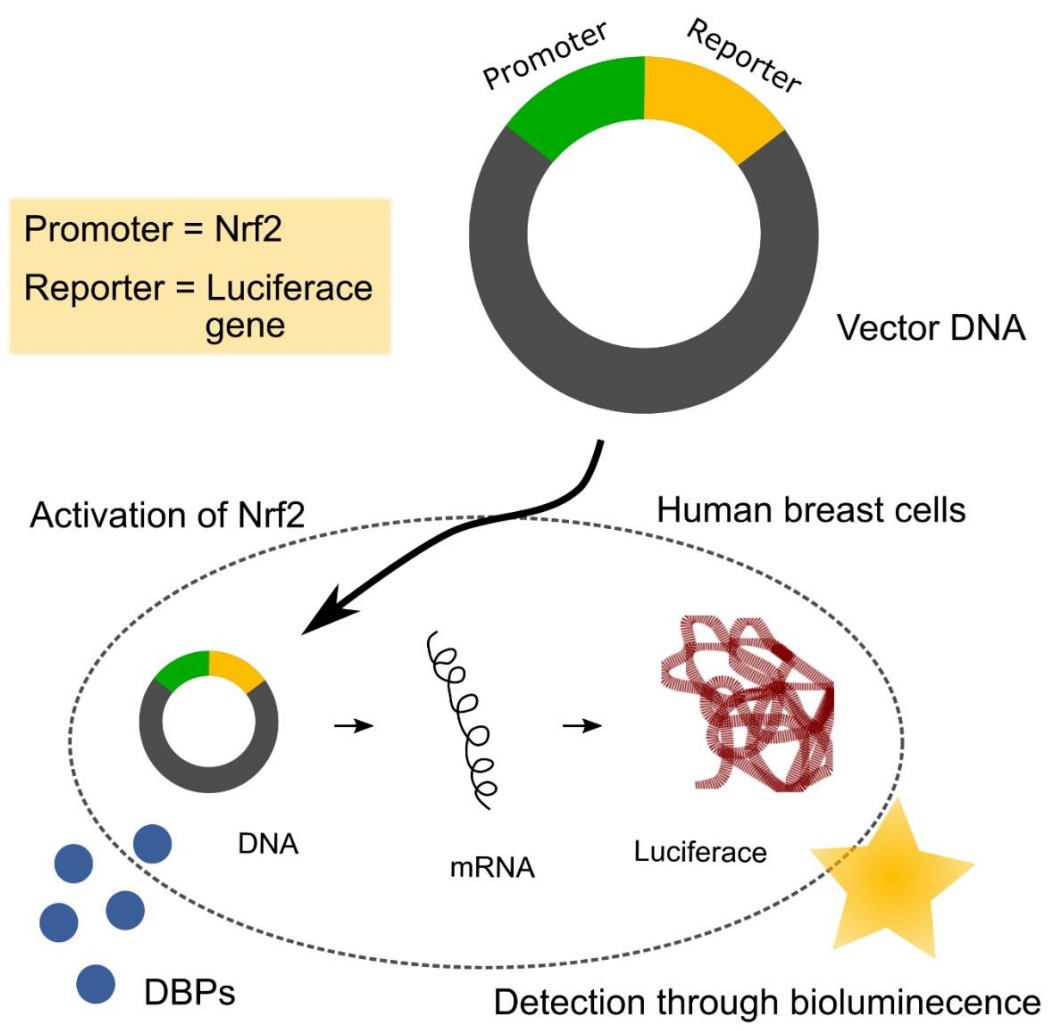

Figure 3. Schematic presentation of bioassay analysis based on adaptive stress response pathways, such as the oxidative stress response. Note that the cells used in bioassays are modified with vector DNA to enable the detection of a cellular response activation.

In one study, the fraction of non-volatile DBPs exerted a higher oxidative stress response than the volatile DBPs, and this higher response from the non-volatile fraction was poorly explained by known compounds (Stalter et al., 2016b). Similar findings have been reported by others (Hebert et al., 2018). This indicates that a majority of DBP toxicity stems from compounds that are not known and that these are likely to comprise molecules that are non-volatile. Hence, there is a need to combine chemical and toxicological investigations focused on this fraction. 



\section{Methodology}

4.1 Mapping DBP formation at four WTPs using different raw water types (Papers I, II)

\subsubsection{Site selection and sample collection}

To study the molecular diversity of the DBPs formed, four water treatment plants in Sweden were chosen: Berggården, located in Linköping (LIN), Borg, located in Norrköping (NOR), Görväln, located in Stockholm (STO) and Bulltofta, located in Malmö (MAL). These treatment plants were chosen to represent differences in raw water types, treatment processes and disinfectants (chlorine and chloramine), but was also based on the potential impact of the research. These water treatment plants belong to large drinking water producer networks, together providing drinking water to over two million people in Sweden. Figure 4 schematically summarizes the features of the four treatment plants.

To capture seasonal differences, including changes in natural organic matter composition, sample collection continued for one year (duplicate samples collected approximately every other month). Sampling points were chosen to cover all key treatment steps, starting with raw water, and ending at an end-user tap; however, this thesis focus primarily on DBP formation and how the DBP mixture changes to an end-user's tap. 

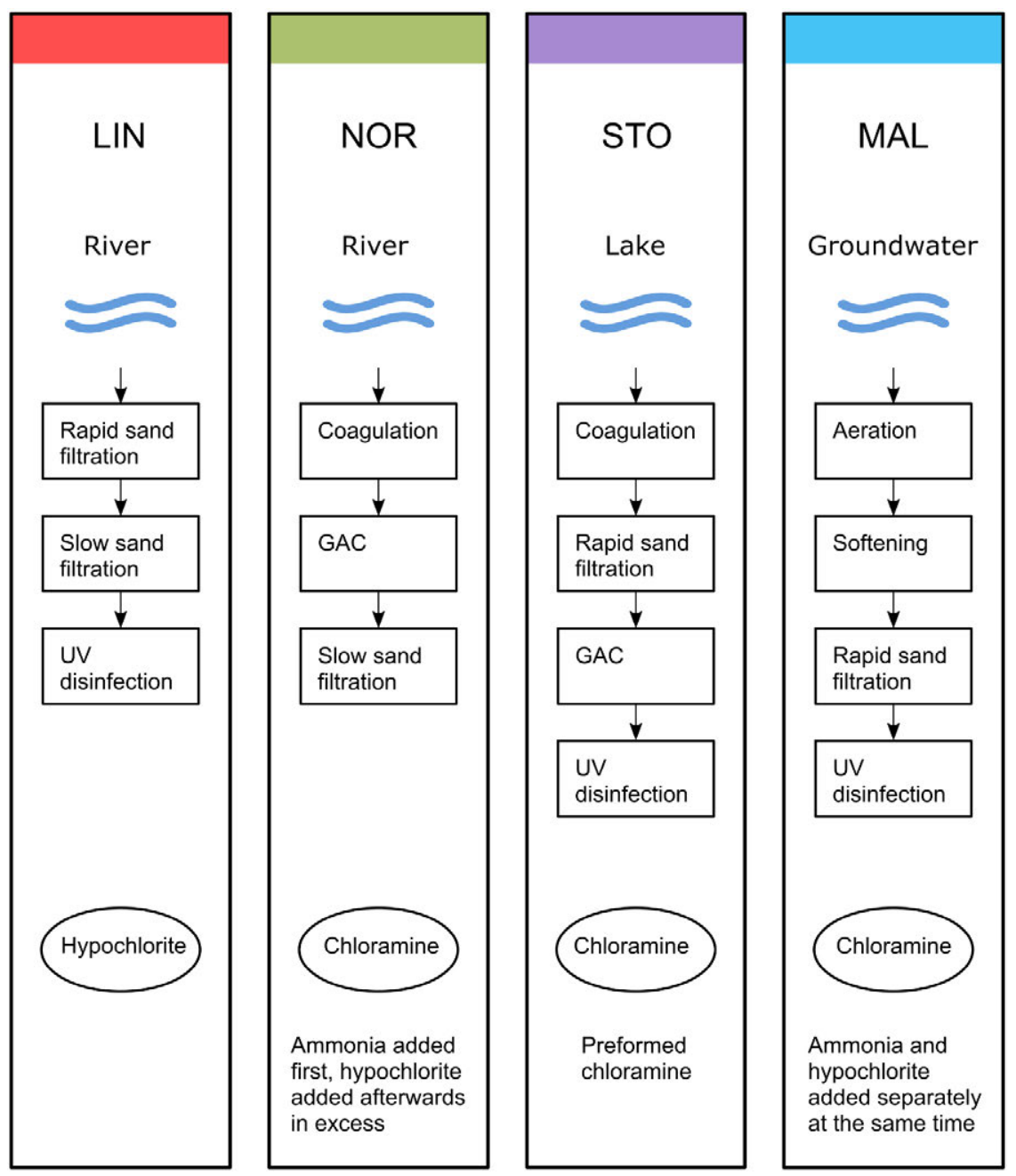

Figure 4. Schematic overview of the water treatment plants chosen for Papers I and II. The figure shows the raw water types, treatment processes and disinfectants used at the four water treatment plants, located in Linköping (LIN), Norrköping (NOR), Stockholm (STO) and Malmö (MAL). 


\subsubsection{Choice of methods}

\section{Non-target screening}

In general, chemical analysis require analytical standards to confirm different chemicals or "targets" detected in a sample. A non-targeted approach, instead, does not involve the search of already known compounds, but rather a screening for different molecules in a sample. In order to detect and characterize not-yet-identified molecules, their mass needs to be measured with high enough accuracy and precision to enable the calculation of exact elemental compositions (Beynon, 1954). Furthermore, since the mixture of organic molecules in freshwater is complex, the masses of thousands of individual molecules need to be resolved (Mopper et al., 2007). To map DBPs as comprehensively as possible a non-target analysis method with broad capacity was needed. Among the high-resolution MS techniques (mentioned in section 3.3), FTICR MS has the highest resolution $(1,000,000)$ and can provide a mass accuracy to five decimal places $(<0.2 \mathrm{ppm}$ error $)$ in a mass range ( $\sim 200-700$ Dalton) that is relevant for NOM and DBP studies (Richardson and Postigo, 2016, Domon and Aebersold, 2006, Hu et al., 2005, McLuckey and Wells, 2001). This resolution is necessary for definitive molecular formulae assignments to a given mass (Koch et al., 2007), and based on the successful application on environmental samples in previous studies (Lavonen et al., 2013, Gonsior et al., 2014), FT-ICR MS was chosen for nontarget screening.

There are different ionization techniques available. For FT-ICR MS, there are three techniques that are soft (ionization of molecules with low likelihood of breaking them into small fragments): electrospray ionization (ESI), matrix-assisted laser desorption/ionization (MALDI), and atmospheric pressure photoionization (APPI) (Mopper et al., 2007). These ionization techniques have different selectivity, which is connected to their different ionization mechanisms, and the most complete information is gained by combining different ionization techniques or modes (Cao et al., 2015, Ohno et al., 2016, Hertkorn et al., 2008). For this work, ESI was chosen for its soft features and because it is easily connected to the FT-ICR MS instrument (Cao et al., 2015). Specifically, ESI, operated in negative mode was used, i.e., negatively charged ions were created. Analysis in the negative mode has shown to cover a larger compositional diversity of detected molecules, compared to analysis in positive mode (Hertkorn et al., 2008). More information about ESI ionization, how an FT-ICR MS instrument operates, and what these mass spectra look like are provided in Appendices $\mathrm{C}$ and $\mathrm{D}$, respectively. 


\subsubsection{FT-ICR MS analysis}

\section{Extraction}

FT-ICR MS analysis requires certain sample preparations (Figure 5). Water samples were filtered through pre-combusted glass fiber filters ( $\mathrm{GF} / \mathrm{F}$, pore size $0.7 \mu \mathrm{m}$, Whatman), limiting the sample matrix to dissolved organic matter (DOM). The DOM was separated from the water using solid phase extraction (SPE). During extraction, organic compounds are retained on the packing material of the SPE cartridge, while the sample water runs through. Based on results and experience from pre-studies and the literature, extractions were performed using a Bond Elut PPL cartridge (Dittmar et al., 2008, Gonsior et al., 2014, Shakeri Yekta et al., 2012, Lavonen et al., 2013, Raeke et al., 2016). The Bond Elut PPL packing material is a polymer made of styrene-divinylbenzene, modified with a nonpolar surface that sorbs a large spectrum of organic molecules through hydrophobic interaction. This is suitable for freshwater analysis, because freshwater organic matter comprises large proportions of non-polar compounds (Lam et al., 2007, Ratpukdi et al., 2009).

Extraction procedures were controlled by running blank samples. A laboratory reagent blank was run every time the extraction was performed using $100 \mathrm{ml}$ 0.1\% formic acid in water (LC-MS ultra CHROMASOLV ${ }^{\circledR}$ ). The blank was treated in the same way as the other samples to evaluate potential contamination from equipment or the environment. Also, DOC of sample water flowing out of the cartridges were measured and compared with original sample DOC, to assess extraction efficiencies.

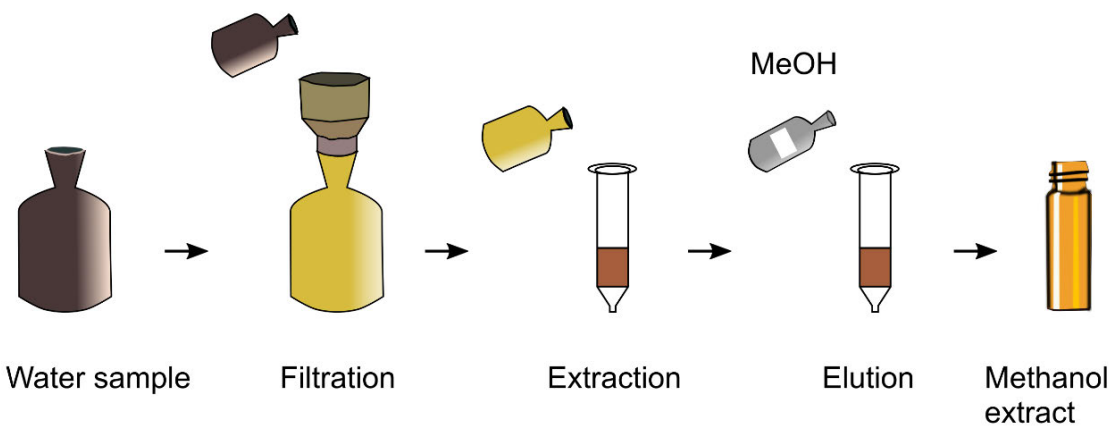

Figure 5. Schematic overview of sample preparation for FT-ICR MS analysis, including filtration and solid phase extraction.

The volumes of water extracted for each sampling point was determined based on the maximum adsorption capacity of the cartridge $(18 \mathrm{mg})$, average DOC levels at the different sampling points and the known approximate extraction efficiency (60\%) (Dittmar et al., 2008). Detailed method descriptions for the extraction procedure are provided in the four individual papers (Papers I-IV). 


\section{FT-ICR MS analysis}

Initial tests were performed to determine optimized dilutions of extracts prior to FT-ICR MS analysis. Samples being compared were diluted to a common calculated extract concentration. Using a Bruker Solarix FT-ICR MS instrument with a magnet of 12 Tesla, a mass resolution of 400000 at $\mathrm{m} / \mathrm{z}$ around 400 in full scan mode, using 4 megawords transients, were achieved. The accuracy was defined as a mass error $<0.2 \mathrm{ppm}$ for all assigned formulae, based on comparisons between experimental and theoretical masses.

\section{Formulae assignment, filtration, and verification}

During formulae assignment, the individual detected $\mathrm{m} / \mathrm{z}$ peaks are assigned to molecular formulae, a mass-matching exercise (performed by computers) in which different element combinations are tested to obtain the "total" molecular mass detected by FT-ICR MS. The assignment was based on exact masses within the allowed mass error, taking all possibilities into account at the same time, i.e., no algorithm of prioritized element combinations was used.

The majority of detected $\mathrm{m} / \mathrm{z}$ peaks could be assigned, and through restrictions concerning the nitrogen rule, a rule based on the valence of chemical bonding applicable to nitrogen-containing compounds (Mopper et al., 2007) and mass error $(<0.2 \mathrm{ppm})$, each $\mathrm{m} / \mathrm{z}$ peak was assigned to a single molecular formula. Approximately half of the assigned formulae were removed due to low amplitude (total ion count $<3000000$ ), highlighting a large drop among molecular formulae near the limit of detection. Filtration criteria, aimed at removing chemically unrealistic molecular formulae $(\mathrm{H} / \mathrm{C} \leq 2.5, \mathrm{C}>0, \mathrm{O} / \mathrm{C} \leq 1$ and $\mathrm{O}>0)$, removed an additional $30-40 \%$ of the formulae. Of the originally detected $\mathrm{m} / \mathrm{z}$ peaks, about $20-40 \%$ passed both assignment and filtration requirements.

The certainty of formula assignment depends on the number of elements allowed. In general, a mass resolution of $\sim 1 \mathrm{mDa}$ can provide unique elemental compositions up to about 500 Da when carbon (C), hydrogen $(\mathrm{H})$, oxygen $(\mathrm{O})$, nitrogen $(\mathrm{N})$ and sulfur $(\mathrm{S})$ are considered (G Marshall et al., 2013). As the mass of a molecule increase, the number of possible elemental combinations increases (Koch et al., 2007). Even more possible combinations arise if additional heteroatoms are considered in the calculations (Koch et al., 2007). Consequently, when chlorine (Cl) and bromine $(\mathrm{Br})$ are introduced into the assignment, additional possible formula combinations arise, increasing the likelihood of falsely assigned formulae, especially at higher masses.

To accurately assign halogenated formulae in this thesis, a verification approach was developed, where the presence of a compound containing the second stable halogen isotope $\left({ }^{37} \mathrm{Cl}\right.$ or $\left.{ }^{81} \mathrm{Br}\right)$ was used to verify each halogenated compound. This approach limits the data, because molecular formulae for which the isotope variant (the compound with ${ }^{37} \mathrm{Cl}$ or ${ }^{81} \mathrm{Br}$ ) is below detection are excluded, and the different abundances of ${ }^{37} \mathrm{Cl}$ and ${ }^{81} \mathrm{Br}$ in nature lead to theoretically easier verification of brominated compounds $\left(\sim 49 \%{ }^{81} \mathrm{Br}\right)$ compared to chlorinated compounds $\left(\sim 24 \%{ }^{37} \mathrm{Cl}\right)$. 
Data analysis and the application of Venn diagrams

A description of the major indices and plots used for the interpretation and visualization of FT-ICR MS data are presented in Appendix E, and the specific approaches to data analysis are found in the individual papers (I-III). Venn diagrams were used in the thesis as a tool to extract and visualize the detailed formula-level information. The creation of a Venn diagram involves sorting based on individual molecular formulae to reveal which formulae are common to a set of different samples. The diagrams were used as tools to investigate differences in DBP formation between the four water treatment plants by separately visualizing different sections of the Venn diagram, e.g., DBP compositions only detected at a specific plant.

\subsubsection{Standard methods for water characterization}

A few water parameters were measured during sample collection, including temperature and total chlorine. At points where total chlorine was measured on-line at the water treatment plants, the on-line measurement was used. For the analysis of tap water samples, an eXact idip photometer (Scantec Nordic, Jonsered), was used. $\mathrm{pH}$ and conductivity were measured within six hours after sample collection using a HACH HQ 40 (Hach, Stockholm). Analysis was performed at room temperature and buffer solutions were used for quality control and regular $\mathrm{pH}$ calibrations. Total nitrogen (TN) was measured using a Shimadzu TOC-V $\mathrm{CSH}_{\mathrm{T}}$ TOC analyzer on duplicate samples of filtered water (Whatman GF/F, $0.7 \mu \mathrm{m}$ porosity). The TN level is the sum of nitrate, nitrite, organic nitrogen, and ammonia in a sample. Certified reference material (Nitrate Nitrogen standard, Sigma-Aldrich) was used as quality control and run every 20 samples.

Bulk characteristics of DOM were analyzed using filtered water (Whatman GF/F, $0.7 \mu \mathrm{m}$ porosity). Dissolved organic carbon (DOC) was measured at an accredited lab connected to each water treatment plant using the nPOC method. Absorbance measurements were recorded in a range of 200-700 $\mathrm{nm}$ using an Ultrospec 2100 pro (Biochrom, Cambridge) and a $5 \mathrm{~cm}$ quartz cuvette. The absorbance at $254 \mathrm{~nm}\left(\mathrm{UVA}_{254}\right)$ and $420 \mathrm{~nm}$ $\left(\mathrm{UVA}_{420}\right)$ are reported. SUVA was calculated by dividing the $\mathrm{UVA}_{254}\left(\mathrm{~cm}^{-1}\right)$ with DOC $\left(\mathrm{mg} \mathrm{C} \mathrm{L}^{-1}\right)$ and is reported in $\mathrm{L} \mathrm{mg}^{-1} \mathrm{~m}^{-1}$. These parameters are briefly described in section 3.3.4. The concentration of polyphenols, targeting aromatic organic molecules with hydroxyl groups, components of special interest in DBP research, was measured using filtered water and is reported as equivalent concentrations of phenol $\left(\mu \mathrm{g} \mathrm{L}^{-1}\right)$. This method protocol is further described in Paper II. 


\subsection{NOM removal and DBP formation at a novel pilot-scale treatment process (Papers III, IV)}

\subsubsection{The pilot-scale process, sample collection and experimental design}

The new treatment technologies evaluated in this thesis included suspended ion exchange (SIX®) technology followed by ozonation and ceramic micro-filtration (CeraMac $\mathbb{R}$ ) with in-line coagulation and granular activated carbon (GAC) filtration. SIX $§$, in particular, was considered a promising technology, with the potential to remove more organic carbon than coagulation. The pilot-scale plant was setup by Norrvatten and Stockholm Vatten och Avfall at Lovö, a conventional full-scale water treatment plant using Lake Mälaren as raw water source (Figure 6).

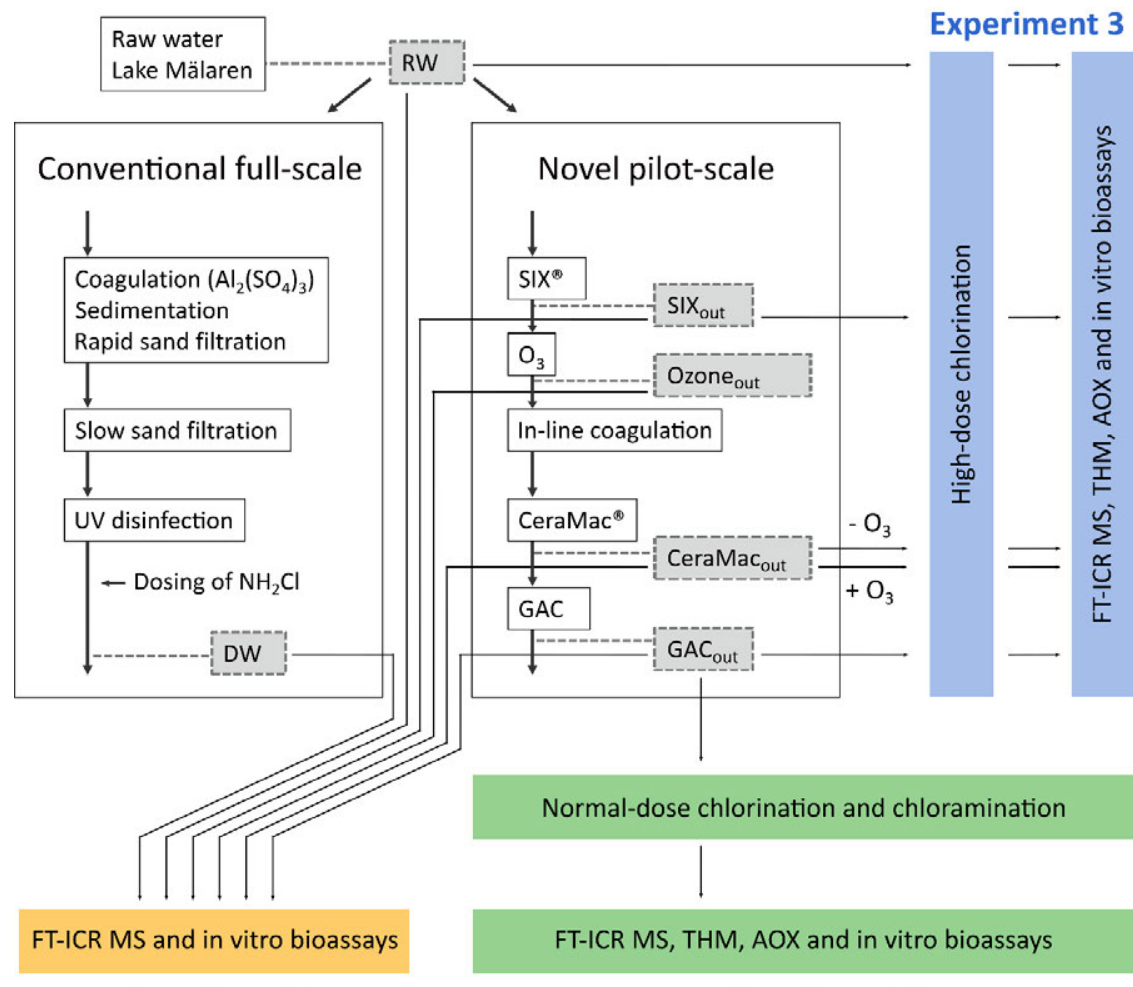

Experiment 1

\section{Experiment 2}

Figure 6. Schematic overview of the treatment techniques evaluated in Papers III and $I V$ and descriptions of sampling points, experimental and analysis approaches. Figure revised from Papers III and IV. 
Normal-dose chlorine and chloramine experiments were carried out on pilot treated water to mimic Swedish water treatment plant conditions. To specifically study how the individual treatment techniques (and their impact on NOM) affected DBP formation, an experimental approach called the DBP formation potential test was chosen (Xie, 2004). In this test, the impact of factors other than NOM affecting DBP formation are minimized. The test is based on the addition of a disinfectant (often chlorine) at a high dose, ensuring that all available NOM that can react, does react. Samples were collected and experiments performed in triplicate. For more detailed information on experimental design, see Paper III or IV.

\subsubsection{Choice of methods}

FT-ICR MS was chosen to investigate treatment-induced changes to NOM and DBPs (Paper III) with a non-targeted approach, see section 4.1.3. The evaluation of treatment-induced NOM changes using FT-ICR MS, requires careful consideration. Fewer ions being available after a treatment might result in the detection of "new" formulae, not because they were absent before, but because they were poorly ionized in the matrix of molecules that were present before the treatment. Therefore, it is difficult to evaluate if there have been actual losses of formulae. These evaluations were therefore centered on differences in relative abundances of $\mathrm{m} / \mathrm{z}$ peaks detected before and after a treatment, because these patterns are more consistent and can be observed from overlapping mass spectra across a range of masses. With the purpose of visualizing the organic matter compositions that were most significantly affected by each treatment, difference plots were created, highlighting the formulae that decreased in relative abundance by more than $50 \%$ after treatment, based on previous studies of FT-ICR mass spectra variations (Raeke et al., 2017).

In addition to bulk analysis like DOC and $\mathrm{UVA}_{254}$ (see Paper III), analysis based on rapid fractionation (Chow et al., 2004) and liquid chromatography organic carbon detection (LC-OCD) (Huber et al., 2011), obtained from a separate campaign at the pilot plant, were included to provide additional size- and compositional information about NOM. Adsorbable organic halogens (AOX) and THM analysis were included to provide quantitative information on DBP formation. AOX cannot distinguish between chlorinated and brominated DBPs but is a good proxy for the total content of adsorbable organic halogens in the sample. THMs were included to obtain quantitative information about the group of DBPs that are regulated in Sweden, and these were measured at an accredited lab.

To assess the toxic effect of the DBP mixtures (Paper IV), three different bioanalytical approaches were chosen, including oxidative stress (Nrf2 activity), genotoxicity (micronucleus test) and aryl hydrocarbon receptor (AhR) activation. These tests evaluate the activation or suppression of different cellular signal pathways, which are related to different attributes of toxicity, i.e., how a toxic chemical induces toxicity (Escher et al., 2012). For example, the Nrf2 signal pathway activates the transcription of genes encoding for proteins that counteract the harmful 
effects caused by electrophilic chemicals initiating the oxidative stress response (Escher et al., 2012). The oxidative stress response is quite a general toxicity assessment because this signal pathway is present in all cell types and can be triggered by a range of chemicals and physical stressors. AhR activation is a more specific signal pathway, triggered by certain compounds only, e.g., dioxin-like molecules (Nagy et al., 2002, Escher et al., 2012). The micronucleus test has been used to assess genotoxicity, for example of pesticides (Bolognesi et al., 2011). The three bioassays were chosen to cover different potential pathways of toxicity induction by the formed DBPs.

\subsubsection{AOX analysis}

AOX analysis is based on the adsorption of organic molecules to activated carbon and the subsequent detection of halide ions from those organic molecules. Certified reference material (4-Chlorophenol solution for AOX determination, Merck Millipore) was run with every batch ( 20) of samples at $50 \mu \mathrm{g} \mathrm{L}^{-1}$ for method quality control, and the detection and quantification limits were determined as $1 \mu \mathrm{g} \mathrm{L}^{-1}$ and $4 \mu \mathrm{g} \mathrm{L}^{-1}$ respectively, based on repeated analysis of blank samples $(n=7)$ and reference material at a concentration of $10 \mu \mathrm{g} \mathrm{L}^{-1}(\mathrm{n}=7)$. The relative standard deviation (RSD), calculated as sample standard deviation divided by sample mean reported in percent, was $2-4 \%$, based on repeated measurements of reference material at $10 \mu \mathrm{g} \mathrm{L}^{-1}(\mathrm{n}=7)$ and $50 \mu \mathrm{g} \mathrm{L}^{-1}(\mathrm{n}=9)$. The method protocol for AOX analysis is provided in Paper III.

\subsubsection{Bioassays}

The toxicological tests were preferentially run using a different solvent (ethanol) than was used for FT-ICR MS analysis (methanol). To enable dual chemical and toxicological assessment of the same extract, one fraction of the methanol extract (5\%) was used for FT-ICR MS analysis and the remainder (95\%) was evaporated, using dimethyl sulfoxide (DMSO) as "keeper" to minimize evaporation of the organic material, and re-dissolved in ethanol. An important concept connected to bioassays is the relative enrichment factor (REF). REF is a concentration factor that shows how concentrated the sample components are in the cell media, compared to the original water. For example, REF50, as being used in Paper IV, means that the sample concentration that the modified cells are exposed to is 50 times higher than the original water sample. REF1 represents original concentrations. For details regarding exact volumes and concentration factors, see Paper IV. 


\subsection{Use of quenching agents}

In previous studies based on FT-ICR MS analysis, quenching agents, i.e., chemicals added to stop DBP formation, have been used by a few, while some have avoided using them completely, to minimize the risk of interference during FT-ICR MS analysis. An initial experiment showed that the $\mathrm{pH}$ adjustment of water samples to 2.5, as part of the extraction protocol, shifted the equilibrium from aqueous $\mathrm{HOCl}$ to gaseous $\mathrm{Cl}_{2}$, resulting in a decrease in measurable free chlorine to below detection $\left(<0.05 \mathrm{mg} \mathrm{L}^{-1}\right)$. However, in samples subject to high-dose chlorination (Papers III and IV), $\mathrm{pH}$ adjustments were not enough to completely remove free chlorine, why a smaller residual remained until the stage of elution. For both AOX and THM analysis, sodium thiosulfate was used to quench residual chlorine.

\subsection{Method limitations}

\section{Sample preparations}

The sample preparation limits which portions of the NOM mixture are included for analysis. In spite of the broad coverage of NOM components retained by the Bond Elut PPL cartridge, this cartridge primarily sorbs compounds that are oxygenated and unsaturated (Li et al., 2017). However, this cartridge can also retain slightly polar compounds, such as phenols, and the $\mathrm{pH}$ adjustment to 2.5 prior to extraction enables many of the molecules that are charged at neutral $\mathrm{pH}$ to be retained. It is important to note that the $\mathrm{pH}$ adjustment itself might have an impact on NOM, e.g., through acid-catalyzed reactions (Tfaily et al., 2011), but a previous study comparing PPL extracts with original samples found such changes to be negligible for FT-ICR MS analysis (Raeke et al., 2016). Extraction selectivity is also linked to the retainment strength, i.e., large, hydrophobic molecules with multiple sites for hydrophobic interactions can be so tightly adsorbed to the cartridge that the elution of these molecules is incomplete (Raeke et al., 2016). Consequently, the NOM compounds not assessed in this thesis due to the selectivity of Bond Elut PPL are mainly hydrophilic compounds and hydrophobic compounds of high molecular mass.

For AOX analysis, sample preparation limits the analysis to DBPs that can be adsorbed to activated carbon. Therefore, hydrophilic DBPs might not be included. Furthermore, after activated carbon is added, the samples are shaken for an hour to facilitate adsorption of organic molecules; hence, volatile DBPs might be missed during this stage.

\section{Limitations of chemical information gained by FT-ICR MS}

FT-ICR MS offers a qualitative analytical approach. The molecules comprising the sample matrix influence ionization, e.g., ions that are more easily ionized become elevated among peaks in the mass spectra (Hertkorn et al., 2007). Therefore, FT-ICR MS cannot be used to analyze quantitatively whether more of a specific DBP is being formed in one treatment plant compared to another. Oxygenated compounds are efficiently ionized with ESI operated in negative mode, such as carboxyl- 
rich compounds, while hydrocarbons and other compounds lacking oxygen have low ionization efficiency (Hertkorn et al., 2007).

A polar portion is needed to hold the charge to become ionized, but it has been suggested that molecules that also contain a non-polar structural element are favored during ESI ionization (Cech and Enke, 2000). This is because the non-polar structural element promotes positioning the molecule at the surface of a droplet (rather than in the middle), enabling these molecules to hold a larger fraction of the excess charge and hence have a higher ESI response (Cech and Enke, 2000). Also, ESI is selective for molecules of a certain mass range at conventional voltages, with an upper limit of $\sim 1000 \mathrm{Da}$ (These and Reemtsma, 2003). Concrete examples of compound groups not typically detected using ESI-FT-ICR MS are carbohydrates and peptides (Mopper et al., 2007, Hertkorn et al., 2007), proteins and cellulose (due to their molecular size) as well as lipids, which are poorly ionized if they are not carboxylic acids.

Another limitation is that FT-ICR MS is unable to provide structural information that could discriminate between isomers, i.e., molecules of identical chemical formula but with different chemical structure, unless additional fragmentation is performed prior to analysis (Hertkorn et al., 2007). Rather, FT-ICR MS is powerful in providing compositional information about the types and diversity of molecular formulae detected in a sample. 



\section{Results}

In Paper I, the compositional variability of FT-ICR MS detected DBPs formed at four water treatment plants (Figure 6) was investigated, revealing that the majority (56\%) of individual halogenated formulae were unique (Figure 7), i.e., detected at one treatment plant only. The high degree of waterworks-specific DBPs can partly be explained by the differences in disinfectants used, e.g., chlorine induced greater formation of DBPs with more chlorine atoms incorporated, compared to chloramine. Also, the presence of bromide in the groundwater source steered the formation towards brominated DBPs.

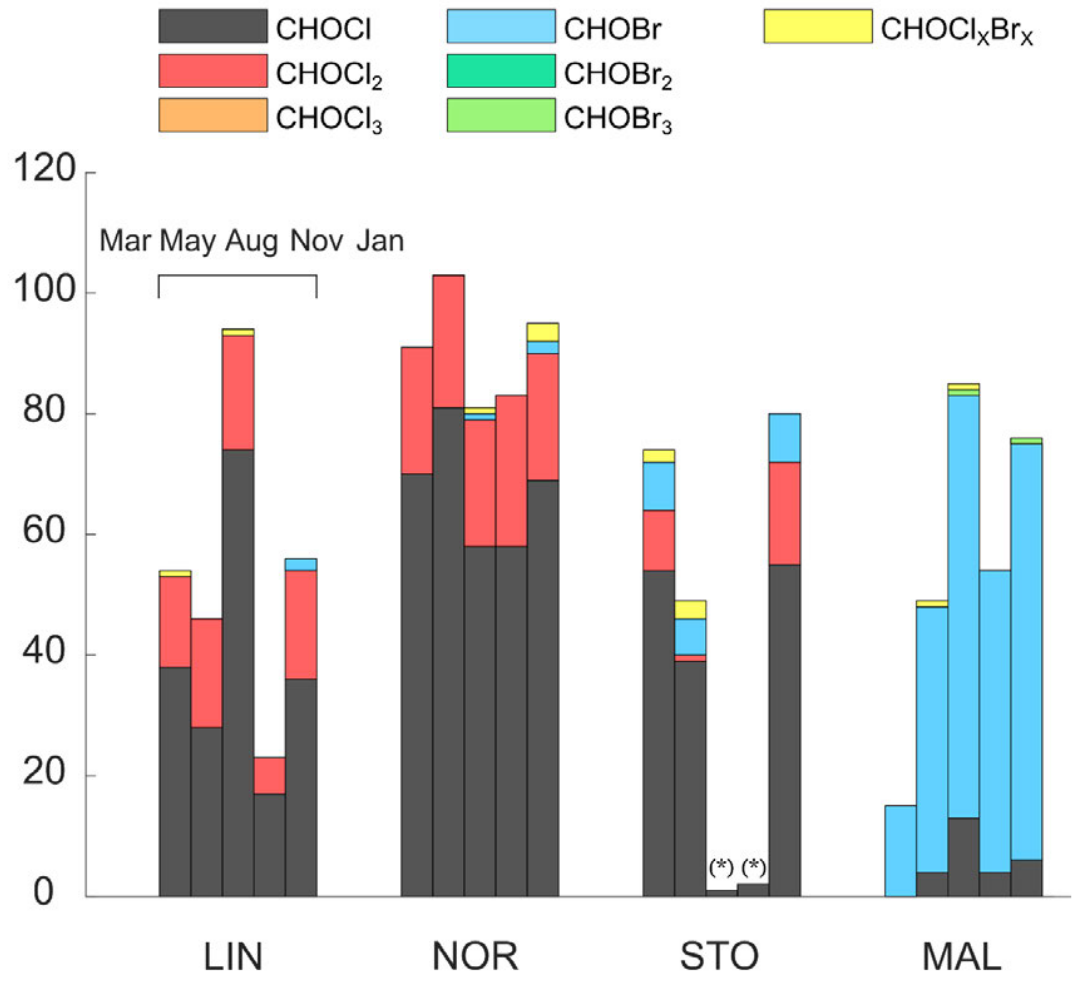

Figure 6. Bar plot showing the number and type of verified DBPs detected at the four Swedish water treatment plants. Figure revised from Paper I. 


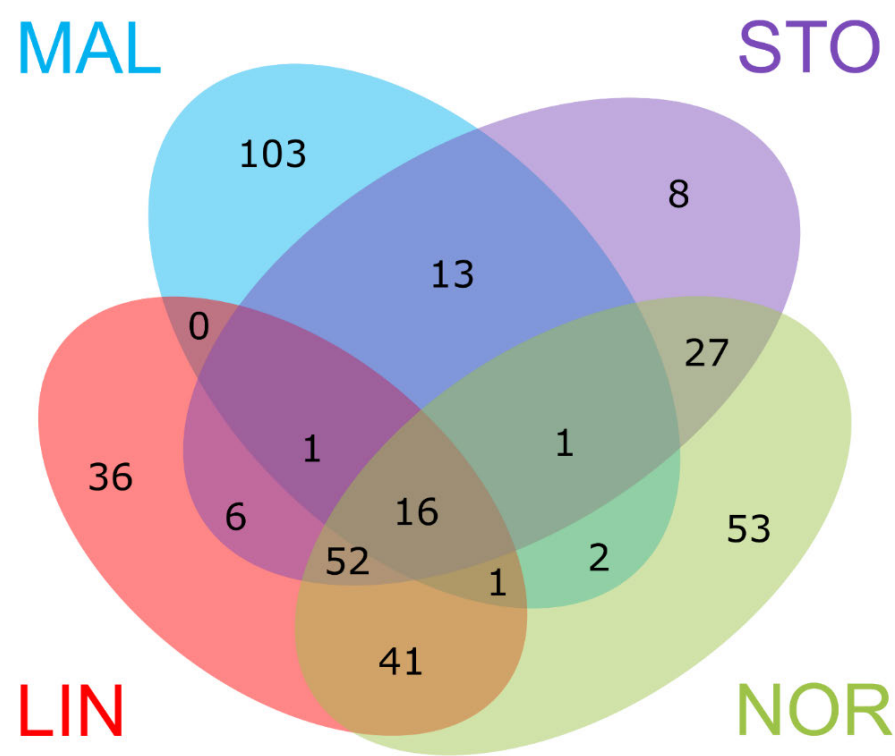

Figure 7. Venn diagram showing the number of verified DBP formulae that were shared between the four water treatment plants, including DBPs formed during the five sampling events combined. Figure revised from Paper $I$.

When raw water molecular DOM compositions were compared between the four treatment plants, the trend was the opposite of that for the DBPs. Most of the DOM compositions detected were shared between all four plants, when comparing both the raw waters and water collected right before chemical disinfection. The unique DBP compositions were linked to the shared DOM compositions, demonstrating that the molecular information about DOM was insufficient to explain the waterworks-specific DBP formation. Rather, the relative abundances of specific structural isomers of DOM before disinfection, which are not distinguishable using FT-ICR MS, were recognized as a remaining important contributor to the formation of waterworks-specific DBPs.

In Paper II, the fates of the DBPs detected in Paper I were investigated (Figure 8). DBP formulae were detected in finished waters, i.e., drinking water leaving the treatment plants, and tap waters, demonstrating that the group of DBPs detected using FT-ICR MS constitute a part of human DBP exposure. However, fewer DBPs were detected in the tap waters, likely due to decomposition or transformation to other DBPs, e.g., volatile DBPs, such as THMs, through hydrolysis reactions. Tap water DBPs had higher average oxidation state of carbon (except at STO), which is likely explained by the continuous reaction between DOM and the disinfectant residual during distribution. Of the DBPs detected in the taps, the majority were detected also after chemical disinfection. Fewer DBPs containing bromine were detected in tap waters, which was likely explained by the 
lower stability and higher hydrolysis rate constants of bromine-containing DBPs. Potential shifts in relative abundances of bromine and chlorine DBP analogues are important because a Br-DBP analogue is about two orders of magnitude more toxic than its Cl-DBP variant.

口Cl-DOM aBr-DOM aCl/Br-DOM
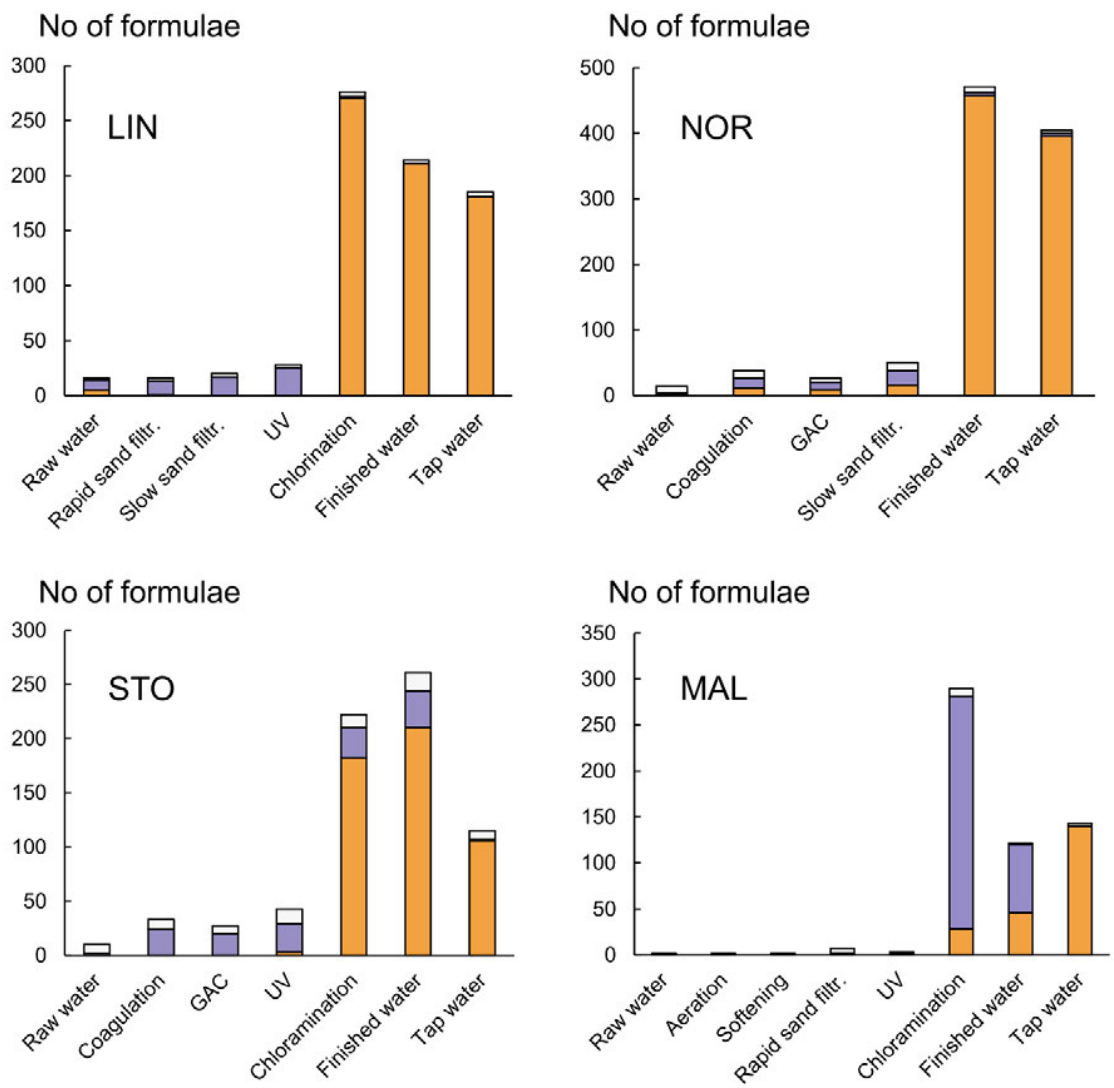

Figure 8. Bar plot showing the number of halogenated $(\mathrm{Cl} / \mathrm{Br})$ molecular formulae (CHO-, CHNO- or CHOS-type) detected at the four water treatment plants, from raw water to tap water. The plots show formulae detected on five sampling events combined, revised from Paper II. Note the different $y$-scales.

In Paper III, a series of new treatment processes were evaluated, based on DOM removal and DBP formation. The individual processes, including suspended ion exchange (SIX $\left.{ }^{\circledR}\right)$, ozonation, in-line coagulation, CeraMac ${ }^{\circledR}$ micro-filtration and granular activated carbon (GAC) filtration, all had clear effects on DOM and showed different selectivity, i.e., they removed DOM of different characteristics. Suspended ion exchange and granular activated carbon removed the largest amounts of organic carbon and had the most substantial effect on THM and AOX formation potentials (Figure 9). Overall, DBP formation was shifted towards higher relative abundances of brominated compounds after each treatment (Figure 10). 
This observation was explained by the presence of a bromide residual in Lake Mälaren, and that this residual became kinetically more important for the DBP reaction, the more DOM was removed during treatment. These shifts depended on the initial chlorine dose, where normal-dose chlorination and chloramination led to the formation of mainly brominated DBPs, while high-dose chlorination shifted DBP formation towards DBPs with multiple chlorine.
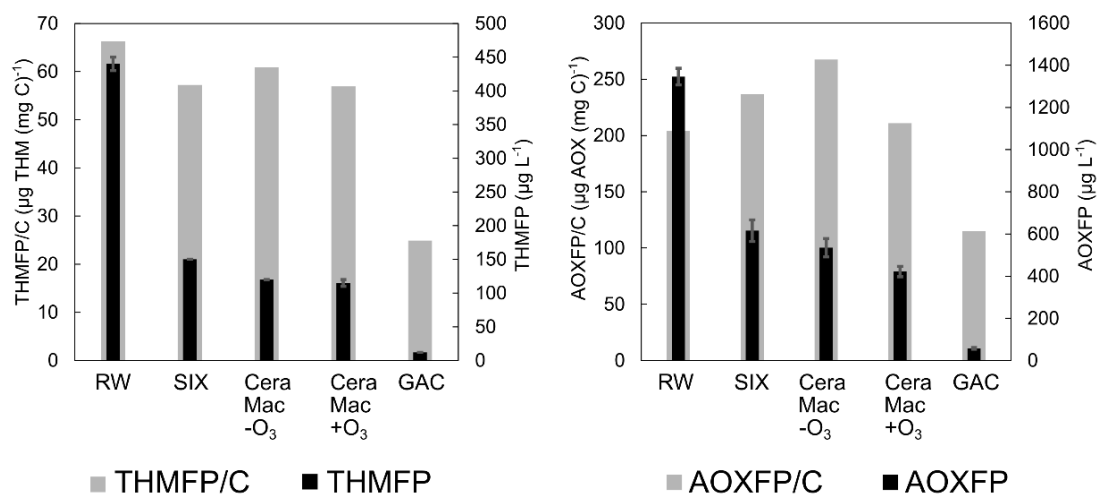

Figure 9. THM formation potential (THMFP), formation per $m g$ carbon (THMFP/C), AOX formation potential (AOXFP) and formation per mg carbon $(A O X F P / C)$ upon high-dose chlorination on samples collected at different stages (clarified in Figure 6) of the pilot treatment process. Figure revised from Paper III. 

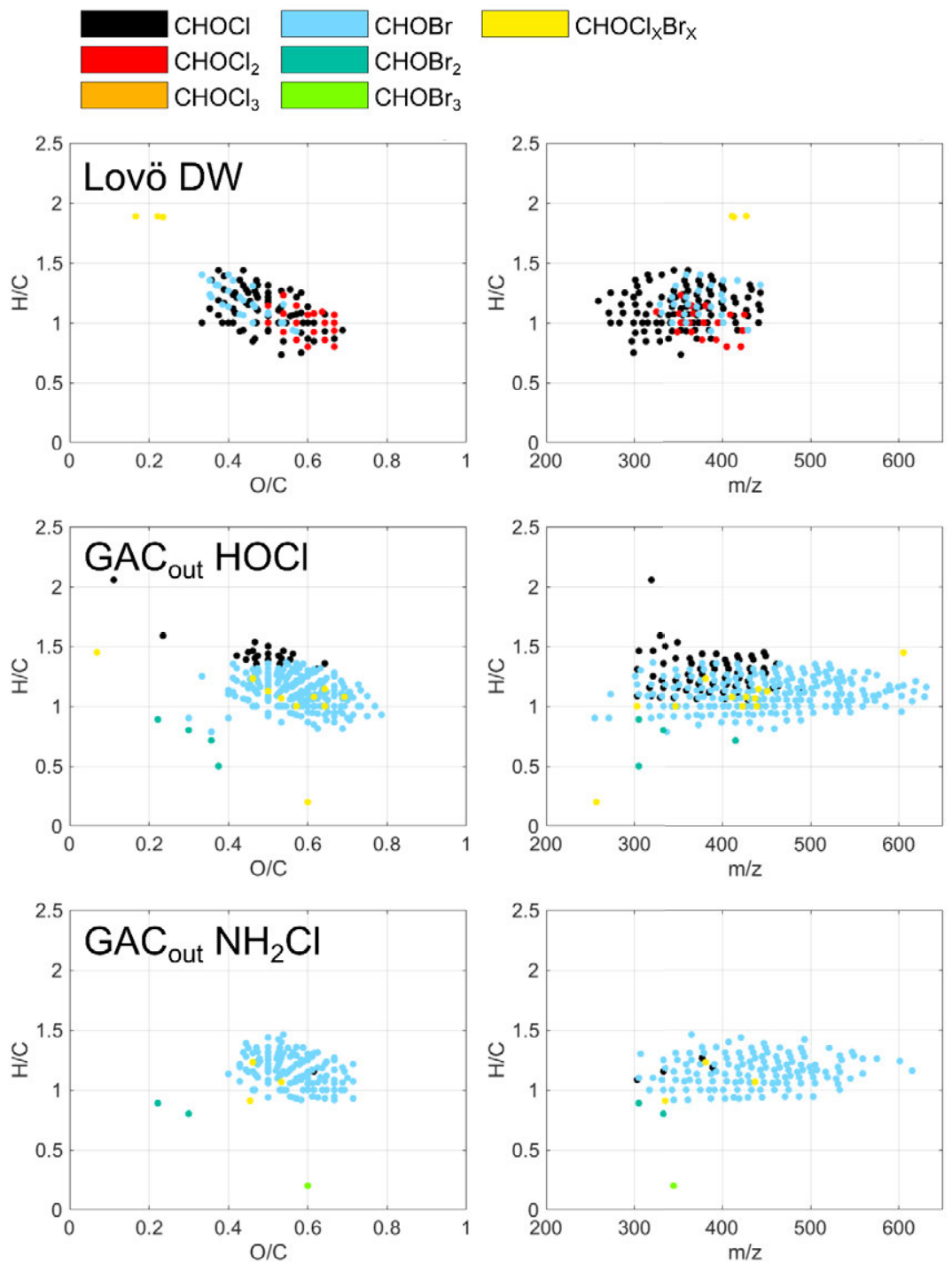

Figure 10. Verified DBP formulae detected in final treated water at Lovö (Lovö $\mathrm{DW})$ and after normal-dose chlorination $(\mathrm{HOCl})$ and chloramination $\left(\mathrm{NH}_{2} \mathrm{Cl}\right)$ of water at the final stage of the pilot treatment (GACout) presented in Van Krevelen diagrams (left panel) and mass edited $H / C$ ratios (right panel). Changes observed between DBP formation at Lovö and the pilot plant (using the same raw water) are linked to the removal of DOM by the pilot treatment processes. Figure revised from Paper III. 
A Conventional treatment process

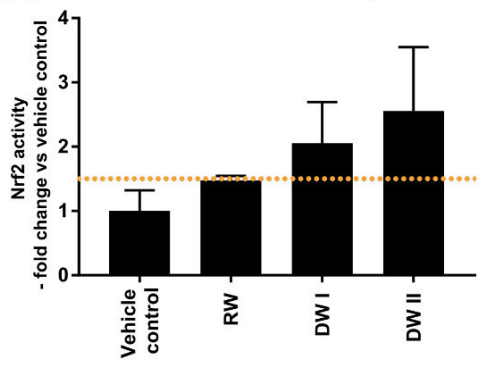

C

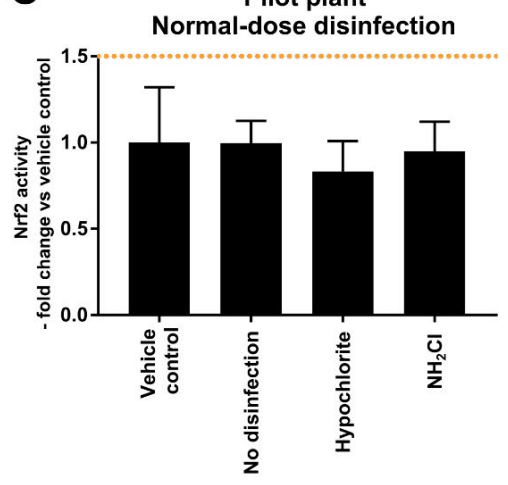

E

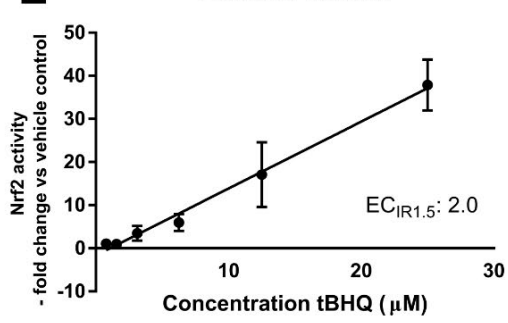

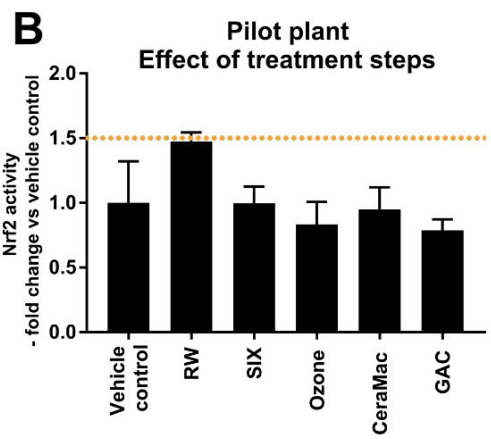

D Pilot plant

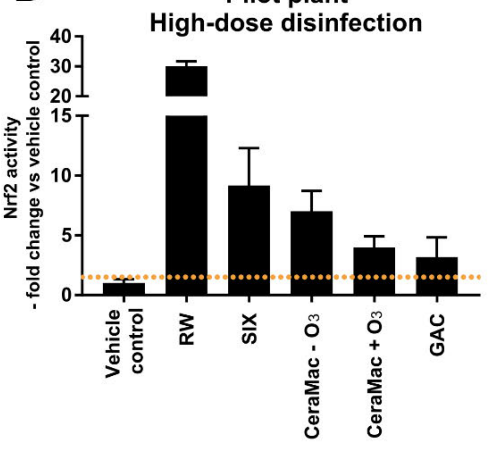

Figure 11. Nrf2 activities at REF 50, i.e., at concentrations 50 times higher than in original water samples. Panel A: Nrf2 activities for raw water and final treated drinking water at the full-scale conventional treatment at Lovö. Panel B: Nrf2 activities at the pilot treatment processes. Panel C: Nrf2 activities after normaldose chlorination and chloramination of pilot treated water. Panel D: Nrf2 activities after high-dose chlorination of samples collected at the different stages of the pilot treatment. Mean and standard deviations $(n=4)$ are shown and tertbutylhydroquinone ( $t B H Q$ ) was used as a positive control (E). Sample names are explained in 4.2.1. Figure revised from Paper IV. 
Paper IV evaluated the same pilot treatment process, but using a different approach, assessing the toxicity from the mixture of DBPs formed (Figure 11). Of the three assessments, Nrf2 activity (oxidative stress) showed the clearest responses to the non-volatile DBP mixture, but these DBPs also induced micronuclei (genotoxicity). The conventionally treated drinking water induced Nrf2 activity above the cut-off for bioactivity (Figure 11:A), while normal-dose chlorination and chloramination of pilot treated water did not (Figure 11:C). This demonstrates that the pilot treatment led to a net decrease of Nrf2-activating compounds, considering both the removal of originally occurring toxic compounds and the formation of new toxic compounds upon disinfection.

High-dose chlorination of water collected at various stages of the pilot treatment provided insight into the capability of individual treatments to reduce the formation of Nrf2-inducing compounds (Figure 11:D). Primarily, it was suspended ion exchange ( $\sim 3$-fold decrease), but also subsequent treatment processes, such as ozonation ( $\sim 2$-fold decrease), that reduced the Nrf2 activity. The effect of granular activated carbon filtration was smaller than expected, considering its large impact on organic carbon levels. Rather, Nrf2-induced activity was best correlated to $\mathrm{UVA}_{254}$ (Figure 12), since some of the treatments that did not affect organic carbon levels but did affect the abundance of UV-absorbing compounds, e.g., ozonation, led to a decrease in disinfection-induced Nrf2 activity.
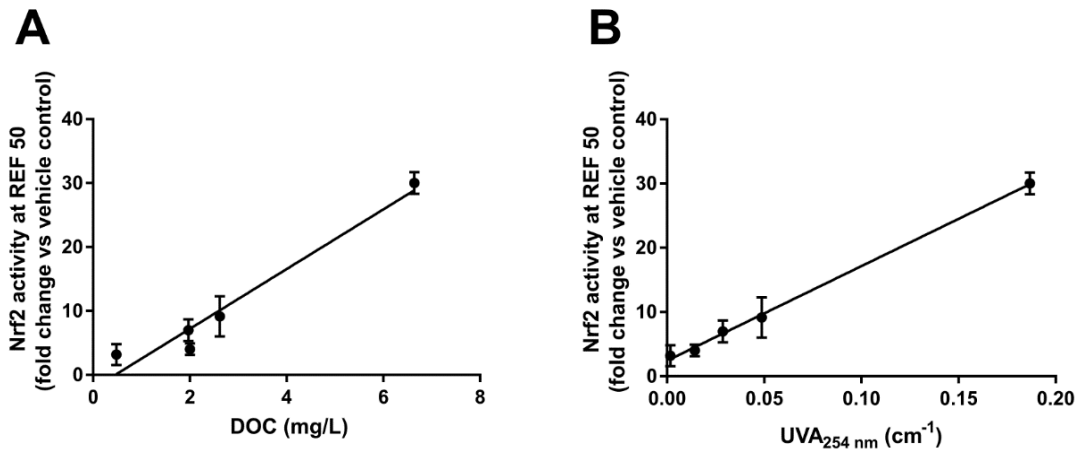

Figure 12. Panel A: Correlation between Nrf2 activity at REF50 and DOC concentration, $y=4.7 x-2.1, r^{2}=0.955 ; p=0.0041$. Panel B: Correlation between Nrf2 activity at REF50 and UVA $254, y=147 x+2.4, \quad r^{2}=0.998 ; p<0.0001$. These associations are obtained from the high-dose chlorination experiment and Nrf2 activities are presented as mean \pm standard deviation, $n=4$. Figure revised from Paper IV. 



\section{Discussion}

\subsection{DBP formation from chlorine vs chloramine disinfection}

The current body of evidence relating health risks with DBPs in drinking water has been demonstrated for chlorinated water (EPA, 2016). Less is known about DBP formation when using chloramine, both regarding potential health risks and their determination through chemical analysis. In this work, including comparisons with individual DBP formulae detected using FT-ICR MS in previous research, a stronger link (more similar DBP formation) between different water treatment plants using chlorine as compared to chloramine was observed (Paper I), inferring less predictable DBP formation from chloramine. This is in line with previous research, which consistently shows low proportions of known DBPs formed from chloramination, compared to chlorination (Hua and Reckhow, 2007b, Xiangru, 2000), also for some of the Swedish water treatment plants investigated here (Postigo et al., 2021). One reason for these observations could be that the specific structures of NOM have a higher impact upon determining the reaction spots when using chloramine, the weaker oxidant (Zhu and Zhang, 2016), therefore leading to a greater variety of DBPs, which are more dependent on available NOM.

Most of the connections observed between DBP composition and disinfectant type in this thesis are consistent with previous findings (Gonsior et al., 2014, Zhang et al., 2012b, Lavonen et al., 2013), e.g., that chlorine produces DBPs with more multiple chlorine atoms incorporated compared to chloramine. However, in Paper III, normal-dose experiments using both chlorine and chloramine, resulted in single bromine-containing DBPs, demonstrating that not only disinfectant type, but also the interplay between bromide and levels and characteristics of DOM, can be more important than disinfectant type in influencing DBP composition.

Future studies designed to compare induced toxic effects from chlorine and chloramine DBP mixtures, e.g., building on Paper IV, along with epidemiological studies targeting groups exposed to both chlorinated and chloraminated drinking water (Säve-Söderbergh et al., 2020), are needed to provide further hands-on insight into important DBP formation differences, depending on the use of chlorine or chloramine.

\subsection{NOM and formation of non-volatile DBPs}

The link between NOM and DBP formation is important because it provides guidance towards how DBP exposure can be reduced by considering choices of raw water sources and through application of NOM removal treatments. Based on comparisons with previous NOM 
fractionation experiments (Harris et al., 2015), DBPs detected using FTICR MS were formed from two distinct NOM fractions, one characterized by aromatic compounds with high oxygen content and one from large carbon-skeletons with more double bonds than oxygen (Paper I). For multiple chlorine DBPs, precursor characteristics were even more clearly defined, e.g., oxygenated compounds with fused aromatic structures or oxygenated rather saturated compounds (Papers I, III), explaining the higher degree of matching $\mathrm{CHOCl}_{2}$ formulae detected at different water treatment plants (Paper I).

We detected aromatic Br-containing DBPs formed upon chloramination (Papers I,II) and similar DBPs have been reported by (Zhai et al., 2014). In general, previous research based on both chlorination and chloramination experiments have shown that Br-DBP formation from NOM of low SUVA, i.e., of low aromatic content, is favored, in contrast to Cl-DBP formation (Liang and Singer, 2003, Duirk and Valentine, 2007). In spite little is known about the specific reactivities of bromamines and various organic compounds (Duirk and Valentine, 2007), the main product likely leading to $\mathrm{Br}-\mathrm{DBP}$ formation in MAL, i.e., $\mathrm{NHClBr}$ (see Figure 2) (Heeb et al., 2014, Zhu and Zhang, 2016) is highly reactive (Heeb et al., 2014), likely also with available activated aromatic precursors.

At a broad level, overall CHO composition could not explain DBP variability among plants (Paper I), highlighting the specificity of DBP formation reactions in relation to total NOM. Also, NOM removal during treatment affected the formation of THMs and AOX differently (Paper III), further demonstrating the specificity of NOM - DBP formation reactions.

A remaining question concerns which DBPs to consider for these NOM removal optimizations. In this thesis, a connection was observed between precursor characteristics and DBP mixture toxicity (Paper IV). Nrf2-induced activity from DBPs was best correlated with the amount of UV-absorbing molecules. This was partly observed from ozonation, which led to an approximately two-fold decrease in Nrf2-induced activity, while having no clear effect on THM or AOX formation potentials. These results suggest that specific precursors, associated with UV-absorbing properties, led to the formation of Nrf2-active DBPs and that ozonation can reduce the formation of such DBPs. Finally, this work highlighted (Paper III) that NOM removal can affect qualitative aspects of DBP formation, such as distribution among Cl-DBPs (less toxic) and Br-DBPs (more toxic), which are worth considering when doing NOM removal optimizations.

\subsection{Potential of suspended ion exchange}

The novel pilot-scale process evaluated in Paper III produced great changes in NOM, and suspended ion exchange had the greatest effect on DBP formation. A comparison between suspended ion exchange and coagulation is of interest because of their mutual high potential for NOM removal and their common role in water treatment. Paper III showed that suspended ion exchange and coagulation both effectively removed humic substances, but there were differences in DOM selectivity connected to molecular mass. Suspended ion exchange removed mid and low molecular mass DOM, 
including hydrophilic compounds, more efficiently than coagulation. Coagulation preferentially removed larger molecules, including aromatic DOM and a group categorized as biopolymers, which was not affected by suspended ion exchange. For the raw water of Lake Mälaren, suspended ion exchange quantitatively removed more DOM $\left(4.4 \mathrm{mg} \mathrm{L}^{-1}\right)$ than the conventional treatment $\left(3 \mathrm{mg} \mathrm{L}^{-1}\right)$ and led to reductions of Nrf2-induced activity (70\%), THM formation potential (66\%), AOX formation potential (54\%) and a decrease in the induction of micronuclei (Papers III, IV).

Importantly, the performance of treatments is strongly dependent on conditions, such as $\mathrm{pH}$ and dose. Therefore, additional studies, including a variety of conditions can bring further insight to the potential of suspended ion exchange. An important advantage of suspended ion exchange is that almost any resin available on the market can be used, which means that the process can be tailored to optimize NOM removal for different water sources (Galjaard et al., 2018, Metcalfe et al., 2015). Furthermore, the costs and energy use ( $\mathrm{CO}_{2}$ emissions) have been estimated to be similar to or lower, than those for enhanced coagulation and sand filtration systems (Galjaard et al., 2018, Galjaard et al., 2011, Metcalfe et al., 2015). However, a few aspects regarding the implementation of suspended ion exchange remain: the ion resin as a potential source of microplastics in drinking water, the management of acquired salt-containing wastewater and increased chloride levels in finished drinking water (which can affect corrosion) as a consequence of resin regeneration (Lavonen et al., 2018).

\subsection{But what is in the tap?}

Until now, there has been no knowledge about whether the group of DBPs detected by FT-ICR MS are present in actual tap waters, but in Paper II it was demonstrated that they are. This means that FT-ICR-MS detected DBPs are stable enough to reach the taps and contribute to DBP exposure. The composition of DBPs changed between the water treatment plants and selected end-user points, for example regarding the presence of brominecontaining species, features that affect mixture toxicity. Knowing that DBP mixtures are dynamic, creates questions regarding if certain shifts are of general nature and if the combined effect of these dynamic changes is favorable or not. The fewer detected tap water Br-DBPs observed through non-target analysis in this thesis (Paper II) suggests (only considering this group of DBPs) that DBP mixtures become less toxic for extended contact times. However, further work based on complementary DBP analysis, including toxicity dimensions, is needed to elucidate if such general DBP mixture changes are occurring. 


\subsection{Method reflections}

\section{Effect of disinfectant dose}

Detailed inter-study comparisons showed that the large pool of DBPs formed in high-dose experiments covers many of the individual DBPs formed at water treatment plants. However, for limited disinfectant doses, such as the situation at Swedish water treatment plants, not all the available organic material reacts, but rather specific structural elements showing favorable reactions rates, i.e., DBP formation at the plants, is limited to a fraction of those determined through high-dose experiments. A few specific impacts on DBP formation related to disinfectant dose were observed: high-dose chlorination experiments formed DBPs with lower DBE and $\mathrm{AI}_{\text {mod }}$ (Paper III), than those formed at the four water treatment plants (Paper I) and the speciation of brominated and chlorinated DBPs were strongly affected by disinfectant dose (Paper III), a feature that is connected to mixture toxicity, and thus important to consider in experimental design.

\section{DBP verification using systematic isotope matching}

Previously, isotope matching was typically performed manually for a limited series of compounds, while in this thesis, it was used as an automated filter that all the data passed through. This verification approach is conservative (it rejects all peaks where the second stable isotopes are not above the intensity threshold) but limits the data to verified compositions, avoiding the misinterpretation and analysis of doubtful formulae. For example, many nitrogen- and sulfur-containing DBPs were assigned, but very few of them were verified. A way to broaden the verification of halogenated compounds in future studies is to allow halogenated formulae based on its verification in a previous sample.

\section{Using FT-ICR MS for DBP analysis}

Overall, FT-ICR MS was shown to be a powerful tool to analyze the composition of DBPs with a non-target approach to reveal qualitative shifts, e.g., from chlorinated to brominated DBP variants. In general, extract dilution optimization was easier for the smaller sample set of Paper III ( $\sim 50$ samples), compared to that used in Papers I and II ( $\sim 350$ samples), where only a few chosen samples were tested as representative of all. Also, the chosen concentration, to which all the samples (independent of treatment plant) were diluted, might have been best optimized for one of the plants. The high-dose chlorination (Paper III) instead required separate dilutions compared to original samples, due to the extensive bleaching, strongly affected the sample matrix in those samples. However, the differences in sample matrix can be accounted for, primarily by considering how samples are compared. As mentioned, few nitrogencontaining DBPs were verified and likely another ionization mode (positive ESI) would be more suitable to capture this DBP class (Lin et al., 2012). 


\section{Using bioassays to assess DBP mixture toxicity}

The approach of assessing the combined toxic effect from DBP mixtures had not been conducted in Sweden before, so this protocol can be used and further fine-tuned for future DBP evaluations of water sources and treatment processes. The approach was efficient for the high-dose chlorination experiment to evaluate the potential of new treatment techniques, but limited effects from DBPs were observed at actual water treatment plant conditions. That can either imply that the toxic effects from DBPs in those water samples were low or that the detection limit of the method need to be improved. However, REF50 is a commonly used enrichment factor and toxic effects have been detected in other drinking water treatment plants when using the same methods (Oskarsson et al., 2021). Importantly, further knowledge about the link between these methods and human health effects are needed to increase their potential as future tools for monitoring, e.g., through approaches such as effect-based trigger values (Escher et al., 2018), where bioassay results are compared against thresholds based on goals for chemical water quality set by the European Water Framework Directive.

\section{A way forward}

Bioassays have the potential to assess the combined effect of DBPs in a mixture (Stalter et al., 2020), taking both qualitative aspects (the presence of DBPs with greater toxicity) and quantitative aspects (higher DBP concentrations) into account, covering both known and unknown DBPs, and other compounds of concern. A remaining challenge is to link the chemical or toxicological footprints of DBPs to actual health risks. Such links might be explained by a few key factors driving the formation of DBPs associated with health risks, or by a few specific compounds contributing significantly to DBP mixture toxicity. Importantly, because the DBP mixture changes during distribution, monitoring at relevant points along the distribution network is necessary to accurately connect health risk and chemical exposure. By adopting an ecotoxicology type of view, considering the entire chain including exposure routes, intake, transport, and biological responses, the missing links will eventually be found.

\subsection{Future perspectives}

The development and introduction of new drinking water treatment technologies capable of removing or inactivating microorganisms, such as membrane technology or ultraviolet (UV) irradiation, might change the role of chemical disinfectants. With multiple barriers against microorganisms, the dosage of chemical disinfectants can be reduced, and their role might be limited to that of a secondary disinfectant, i.e., to prevent microbial growth in the distribution system. This trend highlights the distribution system and its quality, which might be an important player in determining future DBP exposures. 



\section{Conclusions and implications}

Our non-targeted analysis of DBPs formed at four different full-scale water treatment plants, of which only one has detectable levels of THMs, revealed a large variation in non-monitored toxicologically relevant DBPs. Toxic responses due to DBPs are not always connected to total amounts of DBPs but can also be associated with their qualitative properties, such as the relative abundances of chlorine and bromine. Improved removal of organic matter during water treatment generally leads to lower DBP levels, but can also shift the molecular DBP composition, for example towards more toxic bromine-containing DBPs, if the raw water contain bromide. An insight among drinking water producers that both levels and composition of DBPs matters for drinking water quality is important and given the highly waterworks-specific composition of non-volatile DBPs, non-targeted approaches seem necessary to gain parts of that information.

The detailed evaluation of novel treatment techniques delivers insights into their individual potential to decrease NOM and DBP formation. This is useful for drinking water producers when designing or complementing existing treatment trains to improve drinking water quality. Furthermore, the toxic effects of non-volatile DBP mixtures were linked to pre-cursor characteristics, specifically UV-absorbing compounds, suggesting that removing such compounds needs to be a high priority during treatment to reduce the detected toxic effects of non-volatile DBPs.

Non-volatile DBPs were determined as part of actual DBP exposure and their induction of oxidative stress and micronuclei formation (indicator of genotoxicity) in lab experiments, demonstrated their importance in the DBP pool. To summarize, this thesis provides a detailed evaluation of uncharted DBPs as revealed by FT-ICR MS, featuring non-volatile, polyphenol-like compounds. By evaluating their variation among drinking water treatment plants, their formation responses to new NOM-removal treatments, their fate during distribution and their association with mixture toxicity, this thesis contributes insights into the distribution, role, and relevance of these DBPs in drinking water. 



\section{References}

ABUSALLOUT, I., RAHMAN, S. \& HUA, G. 2017. Effect of temperature and $\mathrm{pH}$ on dehalogenation of total organic chlorine, bromine and iodine in drinking water. Chemosphere, 187, 11-18.

ALTENBURGER, R., BRACK, W., BURGESS, R. M., BUSCH, W., ESCHER, B. I., FOCKS, A., MARK HEWITT, L., JACOBSEN, B. N., DE ALDA, M. L., AIT-AISSA, S., BACKHAUS, T., GINEBREDA, A., HILSCHEROVÁ, K., HOLLENDER, J., HOLLERT, H., NEALE, P. A., SCHULZE, T., SCHYMANSKI, E. L., TEODOROVIC, I., TINDALL, A. J., DE ARAGÃO UMBUZEIRO, G., VRANA, B., ZONJA, B. \& KRAUSS, M. 2019. Future water quality monitoring: improving the balance between exposure and toxicity assessments of real-world pollutant mixtures. Environmental Sciences Europe, 31.

AMSTER, I. J. 1996. Fourier transform mass spectrometry. Journal of Mass Spectrometry, 31, 1325-1337.

ANDERSSON, A., HARIR, M., GONSIOR, M., HERTKORN, N., SCHMITT-KOPPLIN, P., KYLIN, H., KARLSSON, S., ASHIQ, M. J., LAVONEN, E., NILSSON, K., PETTERSSON, Ä., STAVKLINT, H. \& BASTVIKEN, D. 2019. Waterworks-specific composition of drinking water disinfection by-products. Environmental Science: Water Research and Technology, 5, 861-872.

BEYNON, J. H. 1954. Qualitative analysis of organic compounds by mass spectrometry. Nature, 174, 735-737.

BOLOGNESI, C., CREUS, A., OSTROSKY-WEGMAN, P. \& MARCOS, R. 2011. Micronuclei and pesticide exposure. Mutagenesis, 26, 19-26.

BOUGEARD, C. M. M., GOSLAN, E. H., JEFFERSON, B. \& PARSONS, S. A. 2010. Comparison of the disinfection by-product formation potential of treated waters exposed to chlorine and monochloramine. Water Research, 44, 729-740.

BOVE, F., SHIM, Y. \& ZEITZ, P. 2002. Drinking water contaminants and adverse pregnancy outcomes: A review. Environmental Health Perspectives, 110, 61-74.

BULL, R. J., RECKHOW, D. A., LI, X., HUMPAGE, A. R., JOLL, C. \& HRUDEY, S. E. 2011. Potential carcinogenic hazards of non-regulated disinfection by-products: Haloquinones, halocyclopentene and cyclohexene derivatives, N-halamines, halonitriles, and heterocyclic amines. Toxicology, 286, 1-19.

BULL, R. J., RECKHOW, D. A., ROTELLO, V., BULL, O. M. \& KIM, J. 2006. Use of Toxicological and Chemical Models to Prioritize DBP Research. Denver, CO: U.S. Environmental Protection Agency.

BUTTERFIELD, C. T. \& WATTIE, E. 1946. Influence of $\mathrm{pH}$ and temperature on the survival of coliforms and enteric pathogens when exposed to chloramine. Public health reports, 61, 157-193.

CAO, D., HUANG, H., HU, M., CUI, L., GENG, F., RAO, Z., NIU, H., CAI, Y. \& KANG, Y. 2015. Comprehensive characterization of natural organic matter by MALDI- and ESI-Fourier transform ion cyclotron resonance mass spectrometry. Analytica Chimica Acta, 866, 48-58.

CECH, N. B. \& ENKE, C. G. 2000. Relating electrospray ionization response to nonpolar character of small peptides. Analytical Chemistry, 72, 2717-2723. 
CHINN, R., LEE, T., KRASNER, S., DALE, M., RICHARDSON, S., PRESSMAN, J., SPETH, T., MILTNER, R. \& SIMMONS, J. Solid-phase extraction of 35 DBPs with analysis by GC/ECD and GC/MS. Proceedings of the American Water Works Association Water Quality Technology Conference, 2007. American Water Works Association Denver, CO.

CHOW, C. W. K., FABRIS, R. \& DRIKAS, M. 2004. A rapid fractionation technique to characterise natural organic matter for the optimisation of water treatment processes. Journal of Water Supply: Research and Technology - AQUA, 53, 85-92.

CHOWDHURY, S., CHAMPAGNE, P. \& MCLELLAN, P. J. 2009. Models for predicting disinfection byproduct (DBP) formation in drinking waters: A chronological review. Science of the Total Environment, 407, 4189-4206.

CROUÉ, J. P., VIOLlEAU, D. \& LABOUYRIE, L. 2000. Disinfection by-product formation potentials of hydrophobic and hydrophilic natural organic matter fractions: $A$ comparison between a low- and a high-humic water. ACS Symposium Series.

DEBORDE, M. \& VON GUNTEN, U. 2008. Reactions of chlorine with inorganic and organic compounds during water treatment-Kinetics and mechanisms: A critical review. Water Research, 42, 13-51.

DING, S. \& CHU, W. 2017. Recent advances in the analysis of nitrogenous disinfection byproducts. Trends in Environmental Analytical Chemistry, 14, 19-27.

DITTMAR, T., KOCH, B., HERTKORN, N. \& KATTNER, G. 2008. A simple and efficient method for the solid-phase extraction of dissolved organic matter (SPE-DOM) from seawater. Limnology and Oceanography: Methods, 6, 230-235.

DOMON, B. \& AEBERSOLD, R. 2006. Mass spectrometry and protein analysis. Science, 312, 212-217.

DUIRK, S. E. \& VALENTINE, R. L. 2007. Bromide oxidation and formation of dihaloacetic acids in chloraminated water. Environmental Science and Technology, 41, 7047-7053.

EDZWALD, J. K. 1993. Coagulation in drinking water treatment: Particles, organics and coagulants. Water Science and Technology, 27, 21-35.

EDZWALD, J. K. 2012. Water quality \& treatment: A handbook on drinking water, Denver, McGraw-Hill.

EPA 2006. National Primary Drinking water Regulations: Stage 2 Disinfectants and Disinfection Byproduct Rule.

EPA 2016. Six-Year Review 3 Technical Support Document for Disinfectants/Disinfection Byproducts Rules. Office of Water (4607M).

EPA, U. 2000. The History of Drinking Water Treatment.

ESCHER, B. I., AÏT-AÏSSA, S., BEHNISCH, P. A., BRACK, W., BRION, F., BROUWER, A., BUCHINGER, S., CRAWFORD, S. E., DU PASQUIER, D., HAMERS, T., HETTWER, K., HILSCHEROVÁ, K., HOLLERT, H., KASE, R., KIENLE, C., TINDALL, A. J., TUERK, J., VAN DER OOST, R., VERMEIRSSEN, E. \& NEALE, P. A. 2018. Effect-based trigger values for in vitro and in vivo bioassays performed on surface water extracts supporting the environmental quality standards (EQS) of the European Water Framework Directive. Science of the Total Environment, 628-629, 748-765.

ESCHER, B. I., DUTT, M., MAYLIN, E., TANG, J. Y. M., TOZE, S., WOLF, C. R. \& LANG, M. 2012. Water quality assessment using the AREc32 reporter gene assay indicative of the oxidative stress response pathway. Journal of Environmental Monitoring, 14, 28772885.

EU 1998. Council Directive 98/83/EC of 3 November 1998 on the quality of water intended for human consumption Official journal of the European Communities, L 330/32.

EVANS, C. D., MONTEITH, D. T. \& COOPER, D. M. 2005. Long-term increases in surface water dissolved organic carbon: Observations, possible causes and environmental impacts. Environmental Pollution, 137, 55-71. 
FARRÉ, M. J., DAY, S., NEALE, P. A., STALTER, D., TANG, J. Y. M. \& ESCHER, B. I. 2013. Bioanalytical and chemical assessment of the disinfection by-product formation potential: Role of organic matter. Water Research, 47, 5409-5421.

FAUST, S. D. \& ALY, O. M. 1983. Chemistry of water treatment, Woburn, Butterworth.

G MARSHALL, A., T BLAKNEY, G., CHEN, T., K KAISER, N., M MCKENNA, A., P RODGERS, R., M RUDDY, B. \& XIAN, F. 2013. Mass resolution and mass accuracy: how much is enough? Mass spectrometry (Tokyo, Japan), 2, S0009-S0009.

GALJAARD, G., KOREMAN, E., METCALFE, D., MOORE, G. \& ERICSSON, P. 2018. Nom-removal by the six $^{\circledR}$-process. Water Practice and Technology, 13, 524-541.

GALJAARD, G., MARTIJN, B., KOREMAN, E., BOGOSH, M. \& MALLEY, J. 2011. Performance evaluation six ${ }^{\circledR}-\operatorname{ceramac}^{\circledR}$ in comparison with conventional pre-treatment techniques for surface water treatment. Water Practice and Technology, 6.

GALLARD, H. \& VON GUNTEN, U. 2002. Chlorination of phenols: Kinetics and formation of chloroform. Environmental Science and Technology, 36, 884-890.

GONSIOR, M., SCHMITT-KOPPLIN, P., STAVKLINT, H., RICHARDSON, S. D., HERTKORN, N. \& BASTVIKEN, D. 2014. Changes in Dissolved Organic Matter during the Treatment Processes of a Drinking Water Plant in Sweden and Formation of Previously Unknown Disinfection Byproducts. Environmental Science \& Technology, 48, 12714-12722.

GOSLAN, E. H., KRASNER, S. W., BOWER, M., ROCKS, S. A., HOLMES, P., LEVY, L. S. \& PARSONS, S. A. 2009. A comparison of disinfection by-products found in chlorinated and chloraminated drinking waters in Scotland. Water Research, 43, 4698-4706.

HARRIS, B. D., BROWN, T. A., MCGEHEE, J. L., HOUSEROVA, D., JACKSON, B. A., BUCHEL, B. C., KRAJEWSKI, L. C., WHELTON, A. J. \& STENSON, A. C. 2015. Characterization of Disinfection By-Products from Chromatographically Isolated NOM through HighResolution Mass Spectrometry. Environmental Science and Technology, 49, 1423914248.

HEBERT, A., FELIERS, C., LECARPENTIER, C., NEALE, P. A., SCHLICHTING, R., THIBERT, S. \& ESCHER, B. I. 2018. Bioanalytical assessment of adaptive stress responses in drinking water: A predictive tool to differentiate between micropollutants and disinfection by-products. Water Research, 132, 340-349.

HEEB, M. B., CRIQUET, J., ZIMMERMANN-STEFFENS, S. G. \& VON GUNTEN, U. 2014. Oxidative treatment of bromide-containing waters: Formation of bromine and its reactions with inorganic and organic compounds-A critical review. Water research, 48, 15-42.

HELLER-GROSSMAN, L., MANKA, J., LIMONI-RELIS, B. \& REBHUN, M. 1993. Formation and distribution of haloacetic acids, THM and tox in chlorination of bromide-rich lake water. Water Research, 27, 1323-1331.

HENDRICKSON, C. L. \& EMMETT, M. R. 1999. Electrospray ionization fourier transform ion cyclotron resonance mass spectrometry. Annual Review of Physical Chemistry. 50, 517-536.

HERTKORN, N., FROMMBERGER, M., WITT, M., KOCH, B. P., SCHMITT-KOPPLIN, P. \& PERDUE, E. M. 2008. Natural organic matter and the event horizon of mass spectrometry. Analytical Chemistry, 80, 8908-8919.

HERTKORN, N., RUECKER, C., MERINGER, M., GUGISCH, R., FROMMBERGER, M., PERDUE, E. M., WITT, M. \& SCHMITT-KOPPLIN, P. 2007. High-precision frequency measurements: Indispensable tools at the core of the molecular-level analysis of complex systems. Analytical and Bioanalytical Chemistry, 389, 1311-1327.

HONGVE, D., RIISE, G. \& KRISTIANSEN, J. F. 2004. Increased colour and organic acid concentrations in Norwegian forest lakes and drinking water - A result of increased precipitation? Aquatic Sciences, 66, 231-238.

HU, Q., NOLL, R. J., LI, H., MAKAROV, A., HARDMAN, M. \& COOKS, R. G. 2005. The Orbitrap: A new mass spectrometer. Journal of Mass Spectrometry, 40, 430-443. 
HUA, G. \& RECKHOW, D. A. 2007a. Characterization of disinfection byproduct precursors based on hydrophobicity and molecular size. Environmental Science and Technology, 41, 3309-3315.

HUA, G. \& RECKHOW, D. A. 2007b. Comparison of disinfection byproduct formation from chlorine and alternative disinfectants. Water Research, 41, 1667-1678.

HUA, G. \& RECKHOW, D. A. 2008. DBP formation during chlorination and chloramination: effect of reaction time, $\mathrm{pH}$, dosage, and temperature. Journal (American Water Works Association), 100, 82-95.

HUA, G. \& RECKHOW, D. A. 2013. Effect of pre-ozonation on the formation and speciation of DBPs. Water Research, 47, 4322-4330.

HUA, G., RECKHOW, D. A. \& ABUSALLOUT, I. 2015. Correlation between SUVA and DBP formation during chlorination and chloramination of NOM fractions from different sources. Chemosphere, 130, 82-89.

HUBER, S. A., BALZ, A., ABERT, M. \& PRONK, W. 2011. Characterisation of aquatic humic and non-humic matter with size-exclusion chromatography - organic carbon detection organic nitrogen detection (LC-OCD-OND). Water Research, 45, 879-885.

HUGHEY, C. A., HENDRICKSON, C. L., RODGERS, R. P., MARSHALL, A. G. \& QIAN, K. 2001. Kendrick mass defect spectrum: A compact visual analysis for ultrahigh-resolution broadband mass spectra. Analytical Chemistry, 73, 4676-4681.

HWANG, C. J., SCLIMENTI, M. J. \& KRASNER, S. W. 2000. Disinfection by-product formation reactivities of natural organic matter fractions of a low-humic water. ACS Symposium Series.

IARC 2004. Monographs on the Evaluation of Carcinogenic Risks to humans. Some Drinkingwater Disinfectants and Contaminants Including Arsenic. Lyon, France International Agency for Research on Cancer.

KIM, S., KRAMER, R. W. \& HATCHER, P. G. 2003. Graphical method for analysis of ultrahighresolution broadband mass spectra of natural organic matter, the van Krevelen diagram. Analytical Chemistry, 75, 5336-5344.

$\mathrm{KOCH}$, B. P. \& DITTMAR, T. 2006. From mass to structure: An aromaticity index for highresolution mass data of natural organic matter. Rapid Communications in Mass Spectrometry, 20, 926-932.

KOCH, B. P., DITTMAR, T., WITT, M. \& KATTNER, G. 2007. Fundamentals of molecular formula assignment to ultrahigh resolution mass data of natural organic matter. Analytical Chemistry, 79, 1758-1763.

KOCH, B. P., WITT, M., ENGBRODT, R., DITTMAR, T. \& KATTNER, G. 2005. Molecular formulae of marine and terrigenous dissolved organic matter detected by electrospray ionization Fourier transform ion cyclotron resonance mass spectrometry. Geochimica et Cosmochimica Acta, 69, 3299-3308.

KRASNER, S. W., WEINBERG, H. S., RICHARDSON, S. D., PASTOR, S. J., CHINN, R., SCLIMENTI, M. J., ONSTAD, G. D. \& THRUSTON, A. D. 2006. Occurrence of a new generation of disinfection byproducts. Environmental Science \& Technology, 40, 7175-7185.

KROLL, J. H., DONAHUE, N. M., JIMENEZ, J. L., KESSLER, S. H., CANAGARATNA, M. R., WILSON, K. R., ALTIERI, K. E., MAZZOLENI, L. R., WOZNIAK, A. S., BLUHM, H., MYSAK, E. R., SMITH, J. D., KOLB, C. E. \& WORSNOP, D. R. 2011. Carbon oxidation state as a metric for describing the chemistry of atmospheric organic aerosol. Nature Chemistry, 3, 133-139.

KÖHLER, S. J., LAVONEN, E., KEUCKEN, A., SCHMITT-KOPPLIN, P., SPANJER, T. \& PERSSON, K. 2016. Upgrading coagulation with hollow-fibre nanofiltration for improved organic matter removal during surface water treatment. Water Research, 89, 232-240. 
LAM, B., BAER, A., ALAEE, M., LEFEBVRE, B., MOSER, A., WILLIAMS, A. \& SIMPSON, A. J. 2007. Major structural components in freshwater dissolved organic matter. Environmental Science and Technology, 41, 8240-8247.

LAVONEN, E., BODLUND, I., DAHLBERG, K., ERIKSSON, U., ANDERSSON, A., BERTILSSON, S., FRÖSEGÅRD, C., FRANKE, V., GOLOVKO, O. \& AHRENS, L. 2018. Dricksvattenberedning med nya reningstekniker - en pilotstudie.

LAVONEN, E. E., GONSIOR, M., TRANVIK, L. J., SCHMITT-KOPPLIN, P. \& KÖHLER, S. J. 2013. Selective chlorination of natural organic matter: Identification of previously unknown disinfection byproducts. Environmental Science and Technology, 47, 22642271.

LEDFORD, E. B., JR., GHADERI, S., WHITE, R. L., KULKARNI, P. S., WILKINS, C. L., GROSS, M. L. \& SPENCER, R. B. 1980. Exact Mass Measurement by Fourier Transform Mass Spectrometry. Analytical Chemistry, 52, 463-468.

LI, Y., HARIR, M., UHL, J., KANAWATI, B., LUCIO, M., SMIRNOV, K. S., KOCH, B. P., SCHMITTKOPPLIN, P. \& HERTKORN, N. 2017. How representative are dissolved organic matter (DOM) extracts? A comprehensive study of sorbent selectivity for DOM isolation. Water Research, 116, 316-323.

LIANG, L. \& SINGER, P. C. 2003. Factors influencing the formation and relative distribution of haloacetic acids and trihalomethanes in drinking water. Environmental Science \& Technology, 37, 2920-2928.

LIN, P., RINCON, A. G., KALBERER, M. \& YU, J. Z. 2012. Elemental composition of HULIS in the Pearl River Delta Region, China: Results inferred from positive and negative electrospray high resolution mass spectrometric data. Environmental Science and Technology, 46, 7454-7462.

LIN WANG, T. C. \& MARSHALL, A. G. 1986. Coulomb broadening in Fourier transform ion cyclotron resonance mass spectrometry. International Journal of Mass Spectrometry and Ion Processes, 68, 287-301.

LIVSMEDELSVERKET. 2015. Livsmedelsverkets föreskrifter om dricksvatten, SLVFS 2001:30 [Online]. Available: http://www.livsmedelsverket.se/globalassets/omoss/lagstiftning/dricksvatten---naturl-mineralv---kallv/slvfs-2001-30-kons-2015-3webb.pdf [Accessed 2017-09-29].

MARSHALL, A. G., HENDRICKSON, C. L. \& JACKSON, G. S. 1998. Fourier transform ion cyclotron resonance mass spectrometry: A primer. Mass Spectrometry Reviews, 17, 1-35.

MCLUCKEY, S. A. \& WELLS, J. M. 2001. Mass analysis at the advent of the 21st century. Chemical Reviews, 101, 571-606.

METCALFE, D., ROCKEY, C., JEFFERSON, B., JUDD, S. \& JARVIS, P. 2015. Removal of disinfection by-product precursors by coagulation and an innovative suspended ion exchange process. Water Research, 87, 20-28.

MOPPER, K., STUBBINS, A., RITCHIE, J. D., BIALK, H. M. \& HATCHER, P. G. 2007. Advanced instrumental approaches for characterization of marine dissolved organic matter: Extraction techniques, mass spectrometry, and nuclear magnetic resonance spectroscopy. Chemical Reviews, 107, 419-442.

MORRIS, J. C. 1966. The acid ionization constant of $\mathrm{HOCl}$ from 5 to $35^{\circ}$. Journal of Physical Chemistry, 70, 3798-3805.

NAGY, S. R., SANBORN, J. R., HAMMOCK, B. D. \& DENISON, M. S. 2002. Development of a green fluorescent protein-based cell bioassay for the rapid and inexpensive detection and characterization of Ah receptor agonists. Toxicological Sciences, 65, 200-210.

NEALE, P. A., ANTONY, A., BARTKOW, M. E., FARRÉ, M. J., HEITZ, A., KRISTIANA, I., TANG, J. Y. M. \& ESCHER, B. I. 2012. Bioanalytical assessment of the formation of disinfection byproducts in a drinking water treatment plant. Environmental Science and Technology, 46, 10317-10325. 
NIEUWENhUIJSEN, M. J., TOLEDANO, M. B., EATON, N. E., FAWELL, J. \& ElLIOTT, P. 2000. Chlorination disinfection byproducts in water and their association with adverse reproductive outcomes: A review. Occupational and Environmental Medicine, 57, 73 85.

OHNO, T., SLEIGHTER, R. L. \& HATCHER, P. G. 2016. Comparative study of organic matter chemical characterization using negative and positive mode electrospray ionization ultrahigh-resolution mass spectrometry. Analytical and Bioanalytical Chemistry, 408, 2497-2504.

OSKARSSON, A., ROSENMAI, A. K., MANDAVA, G., JOHANNISSON, A., HOLMES, A., TRÖGER, R. \& LUNDQVIST, J. 2021. Assessment of source and treated water quality in seven drinking water treatment plants by in vitro bioassays - Oxidative stress and antiandrogenic effects after artificial infiltration. Science of the Total Environment, 758.

PERDUE, E. 2009. Natural Organic Matter.

PLEWA, M. J., WAGNER, E. D., MUELLNER, M. G., HSU, K.-M. \& RICHARDSON, S. D. 2008. Comparative mammalian cell toxicity of N-DBPs and C-DBPs. Urbana, 51, 61801.

POSTIGO, C., ANDERSSON, A., HARIR, M., BASTVIKEN, D., GONSIOR, M., SCHMITT-KOPPLIN, P., GAGO-FERRERO, P., AHRENS, L., AHRENS, L. \& WIBERG, K. 2021. Unraveling the chemodiversity of halogenated disinfection by-products formed during drinking water treatment using target and non-target screening tools. Journal of Hazardous Materials, 401.

QIN, F., ZHAO, Y. Y., ZHAO, Y., BOYD, J. M., ZHOU, W. \& LI, X. F. 2010. A toxic disinfection byproduct, 2,6-dichloro-1,4-benzoquinone, identified in drinking water. Angewandte Chemie - International Edition, 49, 790-792.

RAEKE, J., LECHTENFELD, O. J., TITTEL, J., OOSTERWOUD, M. R., BORNMANN, K. \& REEMTSMA, T. 2017. Linking the mobilization of dissolved organic matter in catchments and its removal in drinking water treatment to its molecular characteristics. Water Research, 113, 149-159.

RAEKE, J., LECHTENFELD, O. J., WAGNER, M., HERZSPRUNG, P. \& REEMTSMA, T. 2016. Selectivity of solid phase extraction of freshwater dissolved organic matter and its effect on ultrahigh resolution mass spectra. Environmental Science: Processes and Impacts, 18, 918-927.

RATPUKDI, T., RICE, J. A., CHILOM, G., BEZBARUAH, A. \& KHAN, E. 2009. Rapid fractionation of natural organic matter in water using a novel solid-phase extraction technique. Water Environment Research, 81, 2299-2308.

RECKHOW, D. A., SINGER, P. C. \& MALCOLM, R. L. 1990. Chlorination of Humic Materials: Byproduct Formation and Chemical Interpretations. Environmental Science and Technology, 24, 1655-1664.

RICHARDSON, S. D. 2002. The role of GC-MS and LC-MS in the discovery of drinking water disinfection by-products. Journal of Environmental Monitoring, 4, 1-9.

RICHARDSON, S. D., PLEWA, M. J., WAGNER, E. D., SCHOENY, R. \& DEMARINI, D. M. 2007. Occurrence, genotoxicity, and carcinogenicity of regulated and emerging disinfection by-products in drinking water: a review and roadmap for research. Mutation Research, 636, 178-242.

RICHARDSON, S. D. \& POSTIGO, C. 2015. Formation of DBPs: State of the Science. Recent Advances in Disinfection By-products, Washington DC, ACS Symposium Series. 1190, 189-214.

RICHARDSON, S. D. \& POSTIGO, C. 2016. Discovery of New Emerging DBPs by High-Resolution Mass Spectrometry. Comprehensive Analytical Chemistry. 71.

RICHARDSON, S. D. \& TERNES, T. A. 2011. Water analysis: Emerging contaminants and current issues. Analytical Chemistry, 83, 4616-4648. 
RICHARDSON, S. D. \& TERNES, T. A. 2018. Water Analysis: Emerging Contaminants and Current Issues. Analytical Chemistry, 90, 398-428.

ROOK, J. J. 1974. Formation of haloforms during chlorination of natural waters. Water Treatment and Examination, 23, 234-243.

ROSTAD, C. E., LEENHEER, J. A., KATZ, B., MARTIN, B. S. \& NOYES, T. I. 2000. Characterization and disinfection by-product formation potential of natural organic matter in surface and ground waters from Northern Florida. ACS Symposium Series.

SERRANO, M., MONTESINOS, I., CARDADOR, M. J., SILVA, M. \& GALLEGO, M. 2015. Seasonal evaluation of the presence of 46 disinfection by-products throughout a drinking water treatment plant. Science of the Total Environment, 517, 246-258.

SHAKERI YEKTA, S., GONSIOR, M., SCHMITT-KOPPLIN, P. \& SVENSSON, B. H. 2012. Characterization of dissolved organic matter in full scale continuous stirred tank biogas reactors using ultrahigh resolution mass spectrometry: A qualitative overview. Environmental Science and Technology, 46, 12711-12719.

SHARMA, V. K., ZBORIL, R. \& MCDONALD, T. J. 2014. Formation and toxicity of brominated disinfection byproducts during chlorination and chloramination of water: A review. Journal of Environmental Science and Health - Part B Pesticides, Food Contaminants, and Agricultural Wastes, 49, 212-228.

STALTER, D., O'MALLEY, E., VON GUNTEN, U. \& ESCHER, B. I. 2016a. Fingerprinting the reactive toxicity pathways of 50 drinking water disinfection by-products. Water Research, 91, 19-30.

STALTER, D., O'MALLEY, E., VON GUNTEN, U. \& ESCHER, B. I. 2020. Mixture effects of drinking water disinfection by-products: Implications for risk assessment. Environmental Science: Water Research and Technology, 6, 2341-2351.

STALTER, D., PETERS, L. I., O'MALLEY, E., TANG, J. Y. M., REVALOR, M., FARRÉ, M. J., WATSON, K., VON GUNTEN, U. \& ESCHER, B. I. 2016b. Sample Enrichment for Bioanalytical Assessment of Disinfected Drinking Water: Concentrating the Polar, the Volatiles, and the Unknowns. Environmental Science and Technology, 50, 6495-6505.

SÄVE-SÖDERBERGH, M., TOLJANDER, J., DONAT-VARGAS, C., BERGLUND, M. \& ÅKESSON, A. 2020. Exposure to drinking water chlorination by-products and fetal growth and prematurity: A nation wide register-based prospective study. Environmental Health Perspectives, 128.

TEUSCHLER, L. K. \& SIMMONS, J. E. 2003. Approaching DBP toxicity as a mixtures problem. Journal / American Water Works Association, 95, 131-138.

TFAILY, M. M., PODGORSKI, D. C., CORBETT, J. E., CHANTON, J. P. \& COOPER, W. T. 2011. Influence of acidification on the optical properties and molecular composition of dissolved organic matter. Analytica Chimica Acta, 706, 261-267.

THESE, A. \& REEMTSMA, T. 2003. Limitations of Electrospray lonization of Fulvic and Humic Acids as Visible from Size Exclusion Chromatography with Organic Carbon and Mass Spectrometric Detection. Analytical Chemistry, 75, 6275-6281.

UECHI, G. T. \& DUNBAR, R. C. 1992. Space charge effects on relative peak heights in fourier transform-ion cyclotron resonance spectra. Journal of the American Society for Mass Spectrometry, 3, 734-741.

VIKESLAND, P. J., OZEKIN, K. \& VALENTINE, R. L. 1998. Effect of natural organic matter on monochloramine decomposition: Pathway elucidation through the use of mass and redox balances. Environmental Science and Technology, 32, 1409-1416.

VILLANUEVA, C. M., CORDIER, S., FONT-RIBERA, L., SALAS, L. A. \& LEVALLOIS, P. 2015. Overview of Disinfection By-products and Associated Health Effects. Current environmental health reports, 2, 107-115.

VOUDRIAS, E. A. \& REINHARD, M. 1988. Reactivities of Hypochlorous and Hypobromous Acid, Chlorine Monoxide, Hypobromous Acidium Ion, Chlorine, Bromine, and Bromine 
Chloride in Electrophilic Aromatic Substitution Reactions with p-Xylene in Water. Environmental Science and Technology, 22, 1049-1056.

WALLER, K., SWAN, S. H., DELORENZE, G. \& HOPKINS, B. 1998. Trihalomethanes in drinking water and spontaneous abortion. Epidemiology, 9, 134-140.

WANG, X., WANG, J., ZHANG, Y., SHI, Q., ZHANG, H., ZHANG, Y. \& YANG, M. 2016. Characterization of unknown iodinated disinfection byproducts during chlorination/chloramination using ultrahigh resolution mass spectrometry. Science of the Total Environment, 554-555, 83-88.

WANG, X., ZHANG, H., ZHANG, Y., SHI, Q., WANG, J., YU, J. \& YANG, M. 2017. New Insights into Trihalomethane and Haloacetic Acid Formation Potentials: Correlation with the Molecular Composition of Natural Organic Matter in Source Water. Environmental Science and Technology, 51, 2015-2021.

WEINBERG, H. S. 2009. Modern approaches to the analysis of disinfection by-products in drinking water. Philosophical Transactions of the Royal Society of London A: Mathematical, Physical and Engineering Sciences, 367, 4097-4118.

WEISHAAR, J. L., AIKEN, G. R., BERGAMASCHI, B. A., FRAM, M. S., FUJII, R. \& MOPPER, K. 2003. Evaluation of specific ultraviolet absorbance as an indicator of the chemical composition and reactivity of dissolved organic carbon. Environmental Science and Technology, 37, 4702-4708.

WOO, Y. T., LAI, D., MCLAIN, J. L., MANIBUSAN, M. K. \& DELLARCO, V. 2002. Use of mechanism-based structure-activity relationships analysis in carcinogenic potential ranking for drinking water disinfection by-products. Environmental Health Perspectives, 110, 75-87.

WU, W. W., CHADIK, P. A., DAVIS, W. M., DELFINO, J. J. \& POWELL, D. H. 2000. The effect of structural characteristics of humic substances on disinfection by-product formation in chlorination. ACS Symposium Series.

WU, W. W., CHADIK, P. A. \& DELFINO, J. J. 2003. The relationship between disinfection byproduct formation and structural characteristics of humic substances in chloramination. Environmental Toxicology and Chemistry, 22, 2845-2852.

XIANGRU, Z., SHINYA, ECHIGO., ROGER, A. MINEAR., MICHAEL, J. PLEWA 2000. Characterization and Comparison of Disinfection By Products of Four Major Disinfectants: In natural organic matter and disinfection by products: characterization and control in drinking water. American chemical society, 761, 299314.

XIE, Y. F. 2004. Disinfection byproducts in drinking water: Formation, analysis, and control, Boca Raton, FL: Lewis.

YANG, M. \& ZHANG, X. 2016. Current trends in the analysis and identification of emerging disinfection byproducts. Trends in Environmental Analytical Chemistry, 10, 24-34.

YANG, X., SHANG, C., LEE, W., WESTERHOFF, P. \& FAN, C. 2008. Correlations between organic matter properties and DBP formation during chloramination. Water Research, 42, 2329-2339.

ZHAI, H., ZHANG, X., ZHU, X., LIU, J. \& JI, M. 2014. Formation of brominated disinfection byproducts during chloramination of drinking water: New polar species and overall kinetics. Environmental Science and Technology, 48, 2579-2588.

ZHANG, H. \& YANG, M. 2018. Characterization of brominated disinfection byproducts formed during chloramination of fulvic acid in the presence of bromide. Science of the Total Environment, 627, 118-124.

ZHANG, H., ZHANG, Y., SHI, Q., HU, J., CHU, M., YU, J. \& YANG, M. 2012a. Study on transformation of natural organic matter in source water during chlorination and its chlorinated products using ultrahigh resolution mass spectrometry. Environmental Science and Technology, 46, 4396-4402. 
ZHANG, H., ZHANG, Y., SHI, Q., REN, S., YU, J., JI, F., LUO, W. \& YANG, M. $2012 b$. Characterization of low molecular weight dissolved natural organic matter along the treatment trait of a waterworks using Fourier transform ion cyclotron resonance mass spectrometry. Water Research, 46, 5197-5204.

ZHANG, H., ZHANG, Y., SHI, Q., ZHENG, H. \& YANG, M. 2014. Characterization of unknown brominated disinfection byproducts during chlorination using ultrahigh resolution mass spectrometry. Environmental Science and Technology, 48, 3112-3119.

ZHANG, L. K., REMPEL, D., PRAMANIK, B. N. \& GROSS, M. L. 2005. Accurate mass measurements by Fourier transform mass spectrometry. Mass Spectrometry Reviews, 24, 286-309.

ZHANG, X.-L., YANG, H.-W., WANG, X.-M., FU, J. \& XIE, Y. F. 2013. Formation of disinfection by-products: Effect of temperature and kinetic modeling. Chemosphere, 90, 634-639.

ZHANG, X., ECHIGO, S., MINEAR, R. A. \& PLEWA, M. J. 2000. Characterization and comparison of disinfection by-products of four major disinfectants. ACS Symposium Series.

ZHU, X. \& ZHANG, X. 2016. Modeling the formation of $\mathrm{TOCl}, \mathrm{TOBr}$ and TOI during chlor(am)ination of drinking water. Water Research, 96, 166-176. 



\section{Appendix}

\section{Appendix A}

\section{Summary of conventional water treatments}

Table A1. Summary of common water treatment technologies that are used at the water treatment plants studied in Papers I and II. Table compiled from (Faust and Aly, 1983, Edzwald, 2012).

\begin{tabular}{|c|c|c|}
\hline $\begin{array}{l}\text { Water } \\
\text { treatment }\end{array}$ & Description & Can remove \\
\hline Coagulation & $\begin{array}{l}\text { Coagulation, also called flocculation, } \\
\text { includes the addition of a chemical to } \\
\text { catalyze floc formation and } \\
\text { sedimentation. The technique has been } \\
\text { used since ancient times and the } \\
\text { dominant chemical agent is aluminum } \\
\text { sulfate }\left(\mathrm{Al}_{2}\left(\mathrm{SO}_{4}\right)_{3}\right) \text {. Lime }\left(\mathrm{Ca}(\mathrm{OH})_{2}\right) \text { and } \\
\text { iron salts such as ferric sulfate } \\
\left(\mathrm{Fe}_{2}\left(\mathrm{SO}_{4}\right)_{3}\right) \text { and ferric chloride }\left(\mathrm{FeCl}_{3}\right) \\
\text { can also be used. Bacteria and algae } \\
\text { have sizes in the upper range of } \\
\text { colloids, viruses in the lower range. } \\
\text { Hence, microorganisms are partially } \\
\text { removed. }\end{array}$ & $\begin{array}{l}\text { Particulate } \\
\text { matter, } \\
\text { humic acids, } \\
\text { microorganisms }\end{array}$ \\
\hline $\begin{array}{l}\text { Sand } \\
\text { filtration }\end{array}$ & $\begin{array}{l}\text { Filtration is a process in which solids, } \\
\text { like bacteria, remaining flocs from } \\
\text { coagulation and precipitated iron and } \\
\text { manganese are removed from a fluid } \\
\text { by passing it through a porous } \\
\text { medium. Sand is the most common } \\
\text { medium for deep-bed filtration. During } \\
\text { sand filtration, a biofilm of bacteria, } \\
\text { fungi and other microorganisms is } \\
\text { formed in the upper sand layer. This } \\
\text { layer is called a schmutzdecke. } \\
\text { Particles are trapped in the matrix and }\end{array}$ & $\begin{array}{l}\text { Microorganisms, } \\
\text { precipitated } \\
\text { iron and } \\
\text { manganese }\end{array}$ \\
\hline
\end{tabular}




\begin{tabular}{|c|c|c|}
\hline & $\begin{array}{l}\text { the microorganisms in the filter sorb } \\
\text { and metabolize organic matter from } \\
\text { the water. The difference between slow } \\
\text { and rapid sand filtration is basically } \\
\text { the time the water spends in the sand } \\
\text { filter. }\end{array}$ & \\
\hline $\begin{array}{l}\text { Activated } \\
\text { carbon } \\
\text { filtration }\end{array}$ & $\begin{array}{l}\text { Activated carbon has a highly porous } \\
\text { structure and a relatively large surface } \\
\text { area and is an excellent adsorbent for } \\
\text { the removal of low concentrations of } \\
\text { organic substances. The major } \\
\text { application is to remove organic } \\
\text { compounds that cause taste and odor } \\
\text { problems. Activated carbon is also } \\
\text { effective for the removal of certain } \\
\text { chemical pollutants, like polynuclear } \\
\text { aromatic hydrocarbons (PAHs). One of } \\
\text { the limitations of carbon filtration is } \\
\text { that the removal efficiency decreases } \\
\text { rapidly as the carbon bed becomes } \\
\text { saturated and needs to be regenerated } \\
\text { or replaced to retain its adsorptive } \\
\text { capacity. }\end{array}$ & $\begin{array}{l}\text { Organic } \\
\text { substances } \\
\text { causing taste } \\
\text { and odor, } \\
\text { organic } \\
\text { pollutants }\end{array}$ \\
\hline Aeration & $\begin{array}{l}\text { When water undergoes aeration, a } \\
\text { metal like iron is oxidized and } \\
\text { precipitated to iron hydroxide } \\
\left(\mathrm{Fe}(\mathrm{OH})_{3}\right) \text {. While precipitated, the iron } \\
\text { can be removed by sedimentation and } \\
\text { filtration. As well as the precipitation } \\
\text { of inorganic contaminants, aeration } \\
\text { can also be used to remove volatile } \\
\text { organic compounds or certain dissolved } \\
\text { gases. }\end{array}$ & $\begin{array}{l}\text { Fe, Mn or other } \\
\text { inorganic } \\
\text { contaminants, } \\
\text { volatile organic } \\
\text { compounds, } \\
\text { dissolved gases }\end{array}$ \\
\hline Softening & $\begin{array}{l}\text { There are different softening } \\
\text { treatments that are effective for the } \\
\text { removal of different types of hardness. } \\
\text { "Cold Lime-Soda Ash" is one technique } \\
\text { to reduce calcium hardness and can be } \\
\text { operated using a Spiractor, where the } \\
\text { water together with added lime or lime } \\
\text { and soda ash }\left(\mathrm{Na}_{2} \mathrm{CO}_{3}\right) \text { enters the }\end{array}$ & $\begin{array}{l}\text { Hardness } \\
\left(\mathrm{Fe}^{3+}, \mathrm{Ca}^{2+} \text { and }\right. \\
\left.\mathrm{Mg}^{2+}\right)\end{array}$ \\
\hline
\end{tabular}




\begin{tabular}{|l|l|}
\hline $\begin{array}{l}\text { bottom of a conical tank which is filled } \\
\text { with a granular catalyst, for example } \\
\text { fine sand. When the water enters the } \\
\text { cone tank it moves up in a spiral } \\
\text { through the suspended catalyst. } \\
\text { Calcium carbonate is formed and } \\
\text { attaches to the granule, creating larger } \\
\text { and larger particles that can be } \\
\text { separated from the water. }\end{array}$ & \\
\hline
\end{tabular}




\section{Appendix B}

\section{Summary of novel water treatments}

Table B1. Summary of the novel treatment techniques evaluated in Papers III and IV. Table compiled from (Lavonen et al., 2018).

\begin{tabular}{|c|c|c|}
\hline $\begin{array}{l}\text { Water } \\
\text { treatment }\end{array}$ & Description & Can remove \\
\hline $\begin{array}{l}\text { Suspended } \\
\text { ion } \\
\text { exchange }\end{array}$ & $\begin{array}{l}\text { Ion exchange is used to remove ions, } \\
\text { e.g., charged organic matter or } \\
\text { inorganic ions. In cation exchange, } \\
\text { positively charged ions are bound to a } \\
\text { negatively charged resin and in anion } \\
\text { exchange, negatively charged ions are } \\
\text { bound to a positively charged resin. } \\
\text { For the removal of organic matter, } \\
\text { anion exchange is preferable because a } \\
\text { large proportion of NOM is negatively } \\
\text { charged at neutral pH. Traditionally, } \\
\text { ion exchange is operated with a fixed } \\
\text { bed but, through applying the ion } \\
\text { exchange in suspended form, a more } \\
\text { continuous regeneration of the resin } \\
\text { can be achieved, increasing the } \\
\text { efficiency of this treatment. } \\
\text { Suspended ion exchange can only } \\
\text { remove dissolved substances, not } \\
\text { particulate matter. }\end{array}$ & $\begin{array}{l}\text { Charged organic } \\
\text { matter, } \\
\text { hardness } \\
\left(\mathrm{Fe}^{3+}, \mathrm{Ca}^{2+} \text { and }\right. \\
\left.\mathrm{Mg}^{2+}\right) \text {, other ions } \\
\text { that bind to the } \\
\text { anion (e.g., } \mathrm{Br}^{-}, \\
\left.\mathrm{NO}_{3}^{-}\right) \text {or cation } \\
\text { exchange resin }\end{array}$ \\
\hline Ozonation & $\begin{array}{l}\text { Ozone is a chemical oxidant that can } \\
\text { offer disinfection, oxidation of } \\
\text { chemical pollutants, mineralization or } \\
\text { bleaching of NOM, increasing the } \\
\text { fraction of bioavailable organic } \\
\text { material, reducing taste and odor or } \\
\text { enabling better operation of } \\
\text { downstream filter or membrane } \\
\text { processes. }\end{array}$ & $\begin{array}{l}\text { Microorganisms, } \\
\text { chemical } \\
\text { pollutants, } \\
\text { bioavailable } \\
\text { NOM (in } \\
\text { combination } \\
\text { with GAC) }\end{array}$ \\
\hline $\begin{array}{l}\text { CeraMac® } \\
\text { micro- } \\
\text { filtration }\end{array}$ & $\begin{array}{l}\text { CeraMac } \circledR \text { is a ceramic microfilter } \\
\text { with a pore size of } 0.1 \mu \mathrm{m} \text {, enabling } \\
\text { the filtration of microorganisms and }\end{array}$ & $\begin{array}{l}\text { Cryptosporidium } \\
\text { (a parasite), } \\
\text { solid particles }\end{array}$ \\
\hline
\end{tabular}




\begin{tabular}{|l|l|l|}
\hline & $\begin{array}{l}\text { particles of sizes larger than this pore } \\
\text { size. }\end{array}$ & \\
\hline $\begin{array}{l}\text { Granular } \\
\text { activated } \\
\text { carbon } \\
\text { filtration }\end{array}$ & $\begin{array}{l}\text { Granular activated carbon (GAC) } \\
\text { filtration functions through adsorption } \\
\text { of different compounds to the highly } \\
\text { porous and large surface areas of } \\
\text { activated carbon. The adsorptive } \\
\text { capacity is reduced with time as the } \\
\text { GAC filter becomes saturated, but a } \\
\text { biofilm is created in the GAC filter } \\
\text { allowing the removal of organic } \\
\text { compounds through biological uptake. }\end{array}$ & $\begin{array}{l}\text { New filter: DOC, } \\
\text { pollutants etc. } \\
\text { exhausted } \\
\text { adsorption } \\
\text { capacity: } \\
\text { bioavailable } \\
\text { organic } \\
\text { compounds }\end{array}$ \\
\hline
\end{tabular}




\section{Appendix C}

\section{Principles of FT-ICR MS analysis}

The FT-ICR MS was developed about four decades ago and has been used to characterize NOM from different sources (Mopper et al., 2007). From the early 2010s, it was applied to study DBPs specifically (Zhang et al., 2012a). Four components constitutes an FT-ICR MS instrument: a magnet, an ICR cell, an ultra-high vacuum system and an advanced data system. The functional core of the instrument is the ICR cell, where both mass analysis and detection take place (Amster, 1996). However, for individual compounds to be analyzed in this cell, the molecules first need to be ionized (become charged). During electrospray ionization (ESI), a high voltage is applied to the sample, which creates fine droplets containing ions (Hendrickson and Emmett, 1999). The solvent in these droplets evaporates gradually, due to an applied heat and pressure drop, leaving the charged molecules closer together (Hendrickson and Emmett, 1999). This increases the electrostatic repulsion between the ions and when this force becomes stronger than the surface tension holding the droplet together, it "explodes" into smaller droplets. This process continues until all the ions are separated in the gas phase and can be introduced to the ICR cell.

The ICR cell is at the center of a powerful magnet, and the force acting on the charged ions from the magnetic field causes them to oscillate in a circular motion (Amster, 1996, Marshall et al., 1998). The frequency of this oscillation, called cyclotron frequency, is dependent on the mass and charge of the ion and the magnetic field strength (Marshall et al., 1998). Because the magnetic field strength is held constant during operation, the mass and charge are the properties that affect the individual cyclotron frequencies of ions in the ICR cell. Consequently, ions with the same mass and charge will form ion packages having the same frequency in the ICR cell. Thus, there are many ions present in the ICR cell simultaneously, but they oscillate with different frequencies. Because the ion motion is crucial for this analysis, an ultra-high vacuum is required to limit the effect on ion motions in the ICR cell (Amster, 1996).

Perpendicular to the magnetic field, an electric field is applied, causing ions of various masses and charges to orbit in phase and accelerating the ions to circulate with larger and larger radius, which enables detection at the detection plates positioned in the outer part of the ICR cell (Mopper et al., 2007). Detection is achieved through image current detection. When the charged ions arrive close to a detector plate, an image current of opposite charge builds up and is registered, i.e., there is no destruction signal detection (Marshall et al., 1998). The frequencies of the ions in the ICR cell can be detected simultaneously and a complex function of multiple sinusoidal curves from the oscillating ions is detected over a time domain (Amster, 1996). Through a sophisticated data system, this complex output undergoes Fourier transform to obtain a frequency, timedomain spectrum, which is then converted to a mass spectrum (Figure C1) through a calibration equation (Marshall et al., 1998). 
The reasons why FT-ICR MS can obtain such ultra-high resolution are that an ion's cyclotron frequency is independent of its velocity, and thus of its kinetic energy (Amster, 1996) and that the mass-to-charge ratio is measured as a frequency, an experimental parameter that can be more accurately measured than any other parameter (Marshall et al., 1998).

One of the major instrumental limitations of FT-ICR MS concerns the so-called space charge effect. This effect is a consequence of the coulomb repulsion force acting on the charged ions that are close together in the ICR cell, i.e., having similar cyclotron frequencies and thus similar $\mathrm{m} / \mathrm{z}$ (Uechi and Dunbar, 1992). The space charge effect can lead to peak broadening (Lin Wang and Marshall, 1986) and have an impact on the relative peak heights during FT-ICR MS analysis (Uechi and Dunbar, 1992). One way to reduce the space charge effect is to reduce the number of charges (ions) in the ICR cell, i.e., to dilute the samples more (Ledford et al., 1980, Zhang et al., 2005). Importantly, this is a balancing act, because a sufficient number of ions $(\sim 100)$ is required for FT-ICR MS detection (Hendrickson and Emmett, 1999).

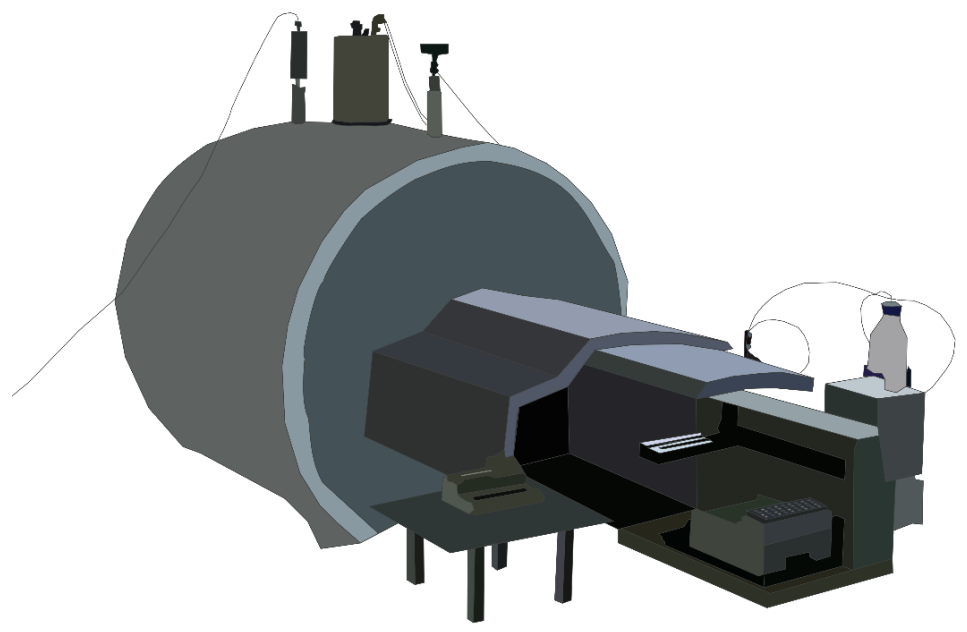

\section{Amplitude}
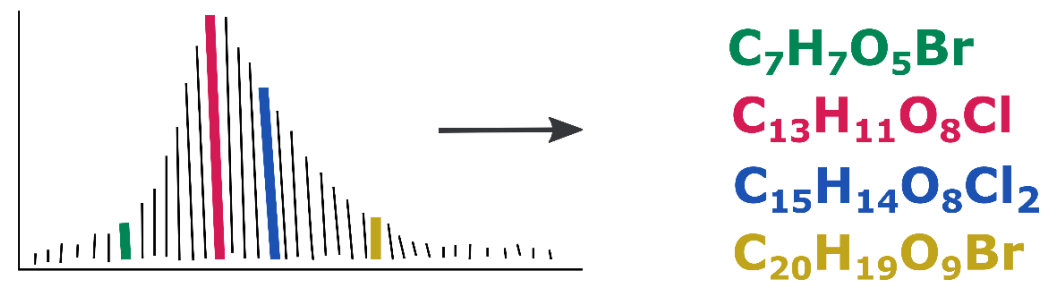

$\mathrm{m} / \mathrm{z}$

Figure C1. A sketch of the FT-ICR MS instrument and an illustration of formula assignment from a mass spectrum. . 


\section{Appendix D}

\section{An FT-ICR mass spectrum - what does it look like?}

The mass spectra follow a wavelike pattern where every other group of peaks with high amplitude is followed by a group of peaks with low amplitude (Figure D1). These peaks represent mainly CHO-formulae. The distance between the groups of high amplitude is $\sim 2 \mathrm{Da}$ and is equal to the mass of two protons or neutrons. The difference reflected in this spectral distance is due to the exchange of $\mathrm{O}(16 \mathrm{Da})$ and $\mathrm{CH}_{2}(12+2 \times 1=14 \mathrm{Da})$, observed as a 2 Da difference.

The spectral distance of $2 \mathrm{Da}$ can also be due to a variation in bonding or substituents resulting in a difference of $2 \mathrm{H}$-atoms. The specific formulae displayed in Figure D1 represent the assigned formula for the peak with highest amplitude in each group. The distance between the groups of high and low amplitude peaks is around $1 \mathrm{Da}$ and is caused by an exchange of ${ }^{12} \mathrm{C}$ to ${ }^{13} \mathrm{C}$.

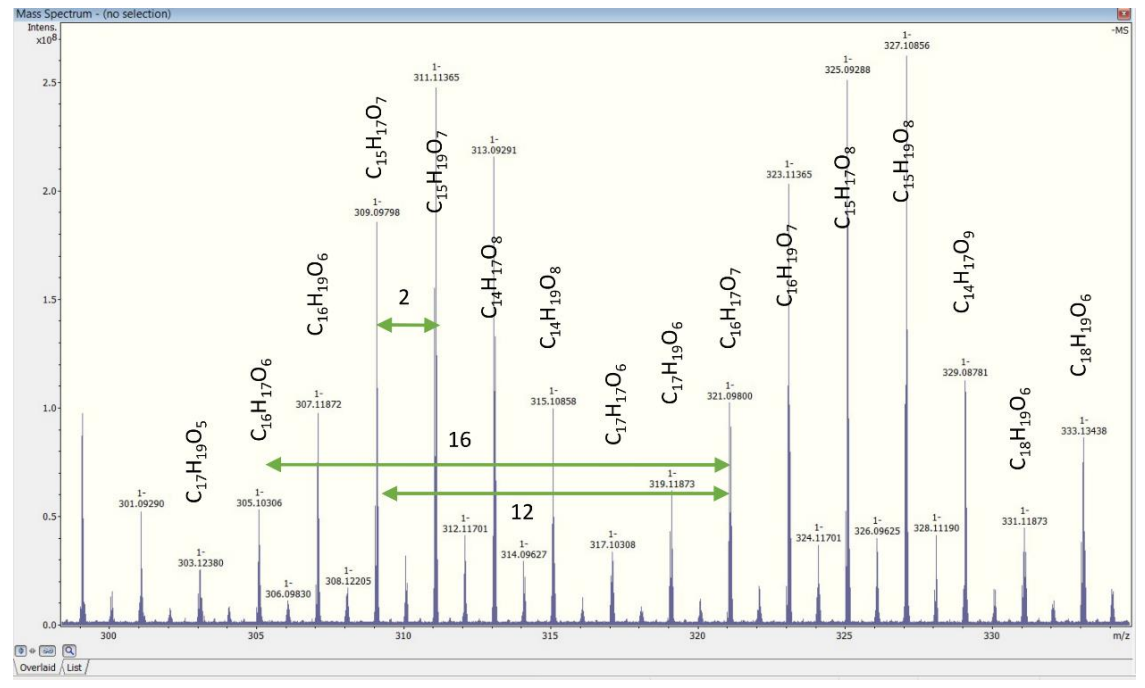

Figure D1. An FT-ICR MS mass spectra spectrum zoomed in at $\mathrm{m} / z \sim 300-330$, highlighting the difference of $2 \mathrm{Da}$ between clusters of formulae, representing an exchange of $\mathrm{CH}_{2}(14 \mathrm{Da})$ to $\mathrm{O}(16 \mathrm{Da})$ or an addition of $\mathrm{H}_{2}$ from lower to higher masses. 
The wavelike pattern is repeatedly visible as the mass spectrum is zoomed in at $\mathrm{m} / \mathrm{z} 307$ (Figure D2). The distance between the high amplitude peaks is $0.3638 \mathrm{Da}$. This mass represents the difference in mass between $\mathrm{O}$ $(15.994915 \mathrm{Da})$ and $\mathrm{CH}_{4}(12+4 \times 1.007825=16.031300 \mathrm{Da})$. The additional peaks observed in between the $\mathrm{CHO}$ molecules represent nitrogen-containing compounds.

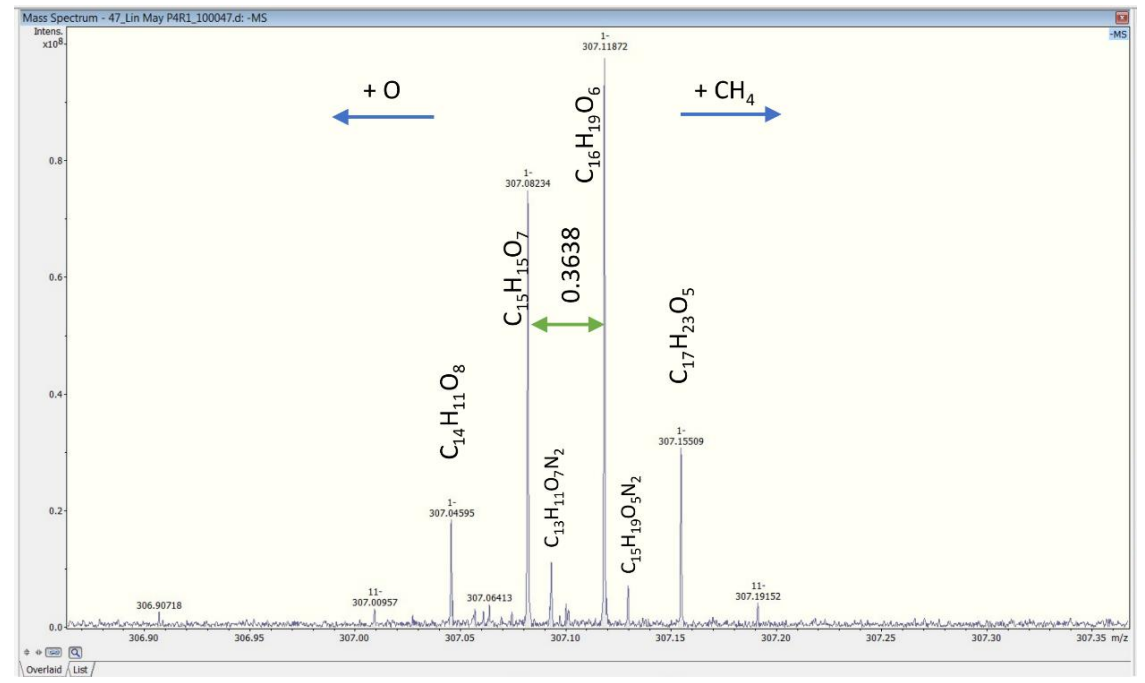

Figure D2. An FT-ICR MS mass spectrum zoomed in at $\mathrm{m} / \mathrm{z} \sim 307$. 


\section{Appendix E}

\section{FT-ICR MS data analysis and interpretation}

Van Krevelen diagram

The van Krevelen diagram (Figure E1) was developed as an approach to facilitate the interpretation of complex mass spectra using the molar ratio of hydrogen to carbon $(\mathrm{H} / \mathrm{C})$ and the molar ratio of oxygen to carbon $(\mathrm{O} / \mathrm{C})$ (Kim et al., 2003). In this diagram, certain structural relationships between formulae can be visualized, such as methylation or demethylation (difference of $\mathrm{CH}_{2}$ ), hydrogenation or dehydrogenation (difference of $\mathrm{H}_{2}$ ), hydration or condensation (difference of $\mathrm{H}_{2} \mathrm{O}$ ), and oxidation or reduction (difference of O) (Kim et al., 2003).

The Van Krevelen diagram has been used to classify regions associated with different groups of biomolecular components, such as lignin, lipids, cellulose, proteins and hydrocarbons (Kim et al., 2003). However, the selectivity during ESI ionization and the mass range of FTICR MS detection limit the extent to which such chemical classification can be used (further discussions of ionization selectivity are provided in section 4.4). However, molecules with low $\mathrm{H} / \mathrm{C}$ ratios of $\sim 0.5$ indicate a deficiency of hydrogen atoms, which could indicate that the molecule has condensed ring structures (Kim et al., 2003). Importantly, the Van Krevelen diagram is a projection, which means that e.g., $\mathrm{C}_{20} \mathrm{H}_{20} \mathrm{O}_{10}$ will plot at the same position as $\mathrm{C}_{10} \mathrm{H}_{10} \mathrm{O}_{5}$ and therefore plots showing $\mathrm{H} / \mathrm{C}$ or $\mathrm{O} / \mathrm{C}$ (y-axis) versus mass (x-axis) are often shown together with Van Krevelen diagrams (Shakeri Yekta et al., 2012).

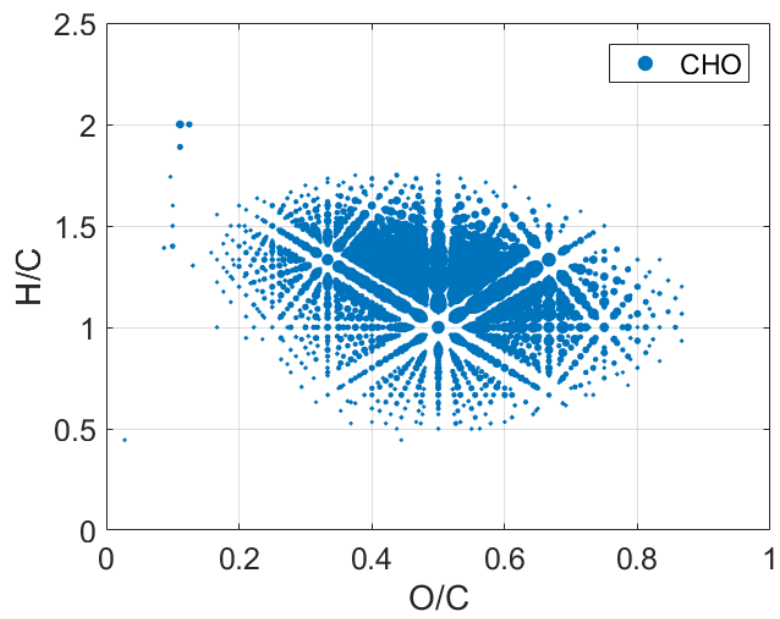

Figure E1. Visualization of CHO formulae detected in a lake sample (LIN, Nov) using the Van Krevelen diagram. Horizontal, vertical, and diagonal patterns can be seen in the diagram, representing different structural relationships, such as oxidation reduction at $H / C=1$, hydrogenation/dehydrogenation at $O / C=0.5$ and methylation/demethylation and hydration or condensation, respectively. 
Kendrick Mass defect

Kendrick Mass defect (KMD) analysis was developed to sort and organize FT-ICR MS-derived formulae in homologous series based on certain structural units, i.e., formulae that differ in composition, corresponding to the masses of structural units, such as $\mathrm{CH}_{2}, \mathrm{COOH}$ or $\mathrm{CH}_{2} \mathrm{O}$, which can be visualized in $2 \mathrm{D}$ plots where structurally related peaks are organized along the same horizontal line (Kim et al., 2003). One base for organization often used is $\mathrm{CH}_{2}$, which means that compounds exhibiting the same composition of heteroatoms, rings and double bonds, with only a change of $\mathrm{CH}_{2}$, will have the same Kendrick mass defect (Hughey et al., 2001). The IUPAC mass of $\mathrm{CH}_{2}$ is $14.01565 \mathrm{Da}$ and the nominal mass is $14 \mathrm{Da}$, so the application of the Kendrick Mass defect includes rescaling the mass spectrum to a "Kendrick" mass scale, according to the following equations (Hughey et al., 2001):

$$
\text { Kendrick mass }=\text { IUPAC mass } \times \frac{14}{14.01565}
$$

Kendrick mass defect $=$ nominal Kenrick mass - exact Kendrick mass

From the original Kendrick mass defect visualization, the application of $\mathrm{KMD} / \mathrm{z}^{*}$ and mass (Figure E2) has been used, where $\mathrm{z}^{*}$ represent the membership of a compound in a nominal mass series. A diagram with $\mathrm{KMD} / \mathrm{z}^{*}$ (y-axis) and mass (x-axis) separates compounds so that each point in the diagram represent one homologous series (Shakeri Yekta et al., 2012). In this diagram, formulae are separated horizontally by the nominal mass difference of $\mathrm{CH}_{2}$, vertically by the exchange of four hydrogen and one carbon with oxygen and diagonally by $\mathrm{H}_{2}$ (Shakeri Yekta et al., 2012).

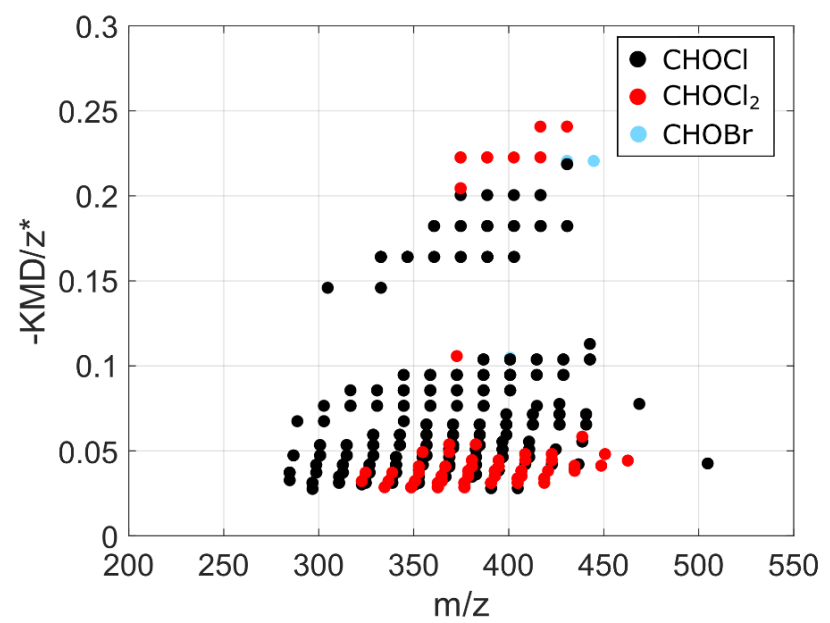

Figure E2. Visualization of halogenated $\mathrm{CHO}$ formulae detected after chemical disinfection (NOR, all sampling occasions combined) using a modified Kendrick mass diagram. The horizontal, vertical, and diagonal patterns represent different structural relationships, such as a difference in $\mathrm{CH}_{2}$, the exchange of four hydrogen and one carbon with oxygen and $H_{2}$, respectively. 
Double bond equivalent (DBE)

Double bond equivalences are defined as the number of $\mathrm{H}_{2}$-molecules that need to be added to a compound to convert all $\Pi$ bonds to single bonds and all ring structures to acyclic structures. A shorter description of DBE is the sum of unsaturated bonds and rings in a molecule (Koch and Dittmar, 2006).

$$
D B E=(C+1)-\frac{(H-N+C l+B r))}{2}
$$

Triple bonds or cumulated double bonds are rare in NOM and therefore a high density of double bonds (DBE/C) can give an indication of aromatic structures (Koch and Dittmar, 2006). Benzene has DBE/C of 0.67 and therefore a higher ratio must involve a condensed ring structure, such as naphthalene (Koch and Dittmar, 2006).

Aromaticity index (AI)

DBE does not take oxygen or sulfur atoms into account, but the introduction of oxygen can reduce the potential number of double bonds at a given DBE due to carbonyl unsaturation. Furthermore, the double bonds between $\mathrm{C}$ and $\mathrm{O}$ do not necessarily contribute to aromaticity. The aromaticity index (AI) was introduced as a measure of aromaticity that considers unsaturated bonds of heteroatoms (Koch and Dittmar, 2006).

$$
A I=\frac{1+C-O-S-0.5 H}{C-O-S-N-P}
$$

This is a more conservative approach (making the assumption that all oxygen atoms are bound as carbonyls and hence not contributing to aromaticity) compared to DBE/C. A modified, less conservative aromaticity index $\left(\mathrm{AI}_{\mathrm{mod}}\right)$, assumes that half of the oxygen is bound with $\sigma$-bonds, primarily as carboxyl oxygen (Koch and Dittmar, 2006). In NOM, carboxyl groups are more common than carbonyl groups, which makes such an assumption legitimate.

$$
A I_{\text {mod }}=\frac{1+C-0.50-S-0.5 H}{C-0.50-S-N-P}
$$

The same threshold values for aromatic and condensed aromatic structures can be used for both $\mathrm{AI}$ and $\mathrm{AI}_{\bmod }, \mathrm{AI}>0.5$ has been used as a minimum criterion for aromatic structure while $\mathrm{AI} \geq 0.67$ has been used as a minimum criterion for a condensed aromatic structure (Koch and Dittmar, 2006). 
Oxidation state of carbon $\left(C_{O S}\right)$

The oxidation state of carbon refers to the charge a carbon atom would have if the electrons shared with more electronegative atoms were lost and electrons shared with less electronegative atoms were gained (Kroll et al., 2011). Even if the oxidation states of individual carbon atoms in a molecule are affected differently upon oxidation, the average oxidation state $\left(\mathrm{C}_{0 S}\right)$ will increase (Kroll et al., 2011). The oxidation state is increased when a bond between carbon and oxygen or another electronegative atom is formed, or when a bond between carbon and hydrogen, or another electropositive atom, is broken (Kroll et al., 2011). In other words, these transformation reactions upon oxidation include functionalization, the addition of polar functional groups, fragmentation, cleavage of C-C bonds and oligomerization, i.e., the combination of two organic molecules. These reactions are related to changes of $\mathrm{C}_{\mathrm{OS}}$ and the number of carbon atoms. The equation to calculate $\mathrm{C}_{\mathrm{O}}$, for compounds only containing $\mathrm{C}, \mathrm{O}$ and $\mathrm{H}$ is given by (Kroll et al., 2011):

$$
C_{O S} \approx 2 O / C-H / C
$$

If a compound contains certain oxygen functional groups or other electronegative compounds, such as chlorine or bromine (as do disinfection by-products), this needs to be accounted for (Andersson et al., 2019). 



\section{Papers}

The papers associated with this thesis have been removed for copyright reasons. For more details about these see:

http://urn.kb.se/resolve?urn=urn:nbn:se:liu:diva-173312 



\section{FACULTY OF ARTS AND SCIENCES}

Linköping Studies in Arts and Sciences No. 805, 2021

Department of Thematic Studies - Environmental Change

Linköping University

SE-581 83 Linköping, Sweden

www.liu.se

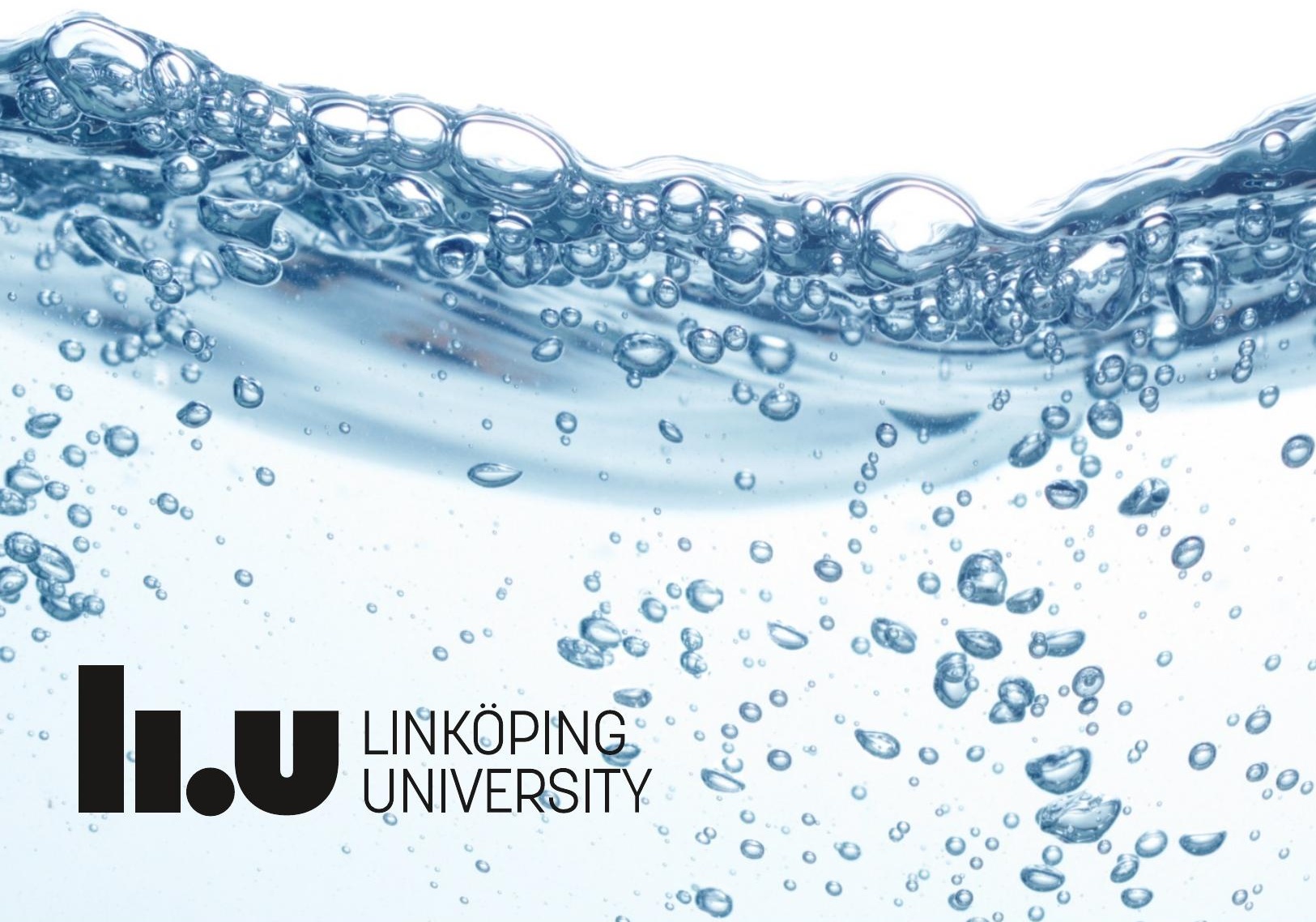

